\title{
Evaluation of Favorable Shale Gas Intervals in Dawuba Formation of Ziyun Area, South Qian Depression
}

\author{
Kun Yuan $\mathbb{D},{ }^{1,2}$ Wenhui Huang, ${ }^{1}$ Xinxin Fang $\left({ }^{3},{ }^{3}\right.$ Ting Wang, ${ }^{1}$ Tuo Lin, ${ }^{1}$ and Rong Chen ${ }^{1}$ \\ ${ }^{1}$ School of Energy Resources, China University of Geosciences (Beijing), Beijing 100083, China \\ ${ }^{2}$ Oil and Gas Resources Survey, China Geological Survey, Ministry of Natural Resources, Beijing 100083, China \\ ${ }^{3}$ Institute of Geomechanics, Chinese Academy of Geological Sciences, Beijing 100081, China
}

Correspondence should be addressed to Kun Yuan; kunyuanogscgs@sina.com and Xinxin Fang; freestarxin@163.com

Received 16 December 2020; Revised 10 January 2021; Accepted 20 May 2021; Published 8 June 2021

Academic Editor: Kun Zhang

Copyright (C) 2021 Kun Yuan et al. This is an open access article distributed under the Creative Commons Attribution License, which permits unrestricted use, distribution, and reproduction in any medium, provided the original work is properly cited.

A series of qualitative descriptions and quantitative analyses was used to determine the lithofacies characteristics and recognize the favorable shale intervals of Dawuba Formation in the Ziyun area of South Qian Depression. The qualitative descriptions include core description and scanning electron microscope (SEM) observation. The quantitative analyses include X-ray diffraction, total organic content analysis, vitrinite reflectance, maceral composition, porosity, and permeability, as well as gas and element composition. The Dawuba Formation could be divided into four members. In general, the shale in the first and third members showed similarly high organic matter content with most samples in range of $2-2.5 \%$ and higher brittle mineral content with a content of quartz $40.53 \%$ and $33.21 \%$, respectively, compared with the other two members, as well as high gas content. However, the first member shale samples exhibited much higher porosity and permeability than the third member shale samples. Furthermore, the shale gas in the first member was chiefly composed of methane (average: $83.63 \%$ ), while that in the third member mainly consisted of nitrogen (average: 79.92\%). Hence, the first member should be regarded as the most favorable target.

\section{Introduction}

In recent years, the success of shale oil and gas exploration and development in North America, such as the Barnett shale with tremendous cumulative gas production, has driven and promoted the development of shale oil and gas industry in China [1-8]. The industrial breakthroughs of shale gas exploration and development in China were achieved mainly in the Ordovician Wufeng and Silurian Longmaxi Formation marine shale reservoirs in Weiyuan, Zhaotong, and Jiaoshiba areas in the southern Sichuan Basin, where the shale gas output reached 10 billion cubic meters in 2019 [9-14]. Although the strata, pattern, mechanism, and geological factors for shale gas source and accumulation were different for different areas, such as in the Weiyuan block and Xiuwu basin $[7,8]$, the high-quality shale section is generally located at the top of Wufeng Formation and the bottom of Longmaxi Formation, in which the biogenic silica caused by frequent volcanic activities hugely developed $[13,15,16]$. However, in the Lower Cambrian shales, such as the shale in Xiuwu basin, the hydrothermal silica occupied a large proportion [13, 14]. Although the massively developed reverse faults in the complex geological structure areas outside the basin damaged the sealing property of the whole reservoir and induced the hydrocarbon loss and nitrogen entry [7], China Geological Survey firstly discovered that the Sinian and Cambrian systems in these areas also obtained highyielding industrial shale gas airflow [6]. Shale oil exploration and development in China mainly focus on the widely developed continental shale in the north, including Ordos Basin, Songliao Basin, Tarim Basin, and Bohai Bay basin [17-22]. Shale oil exploration in the 2nd member of the Kondian Formation in Cangdong Sag of Bohai Bay Basin has made great breakthroughs, and industrial oil flows have been obtained in several wells such as KN9 and GD6 $\times 1$ [23]. 


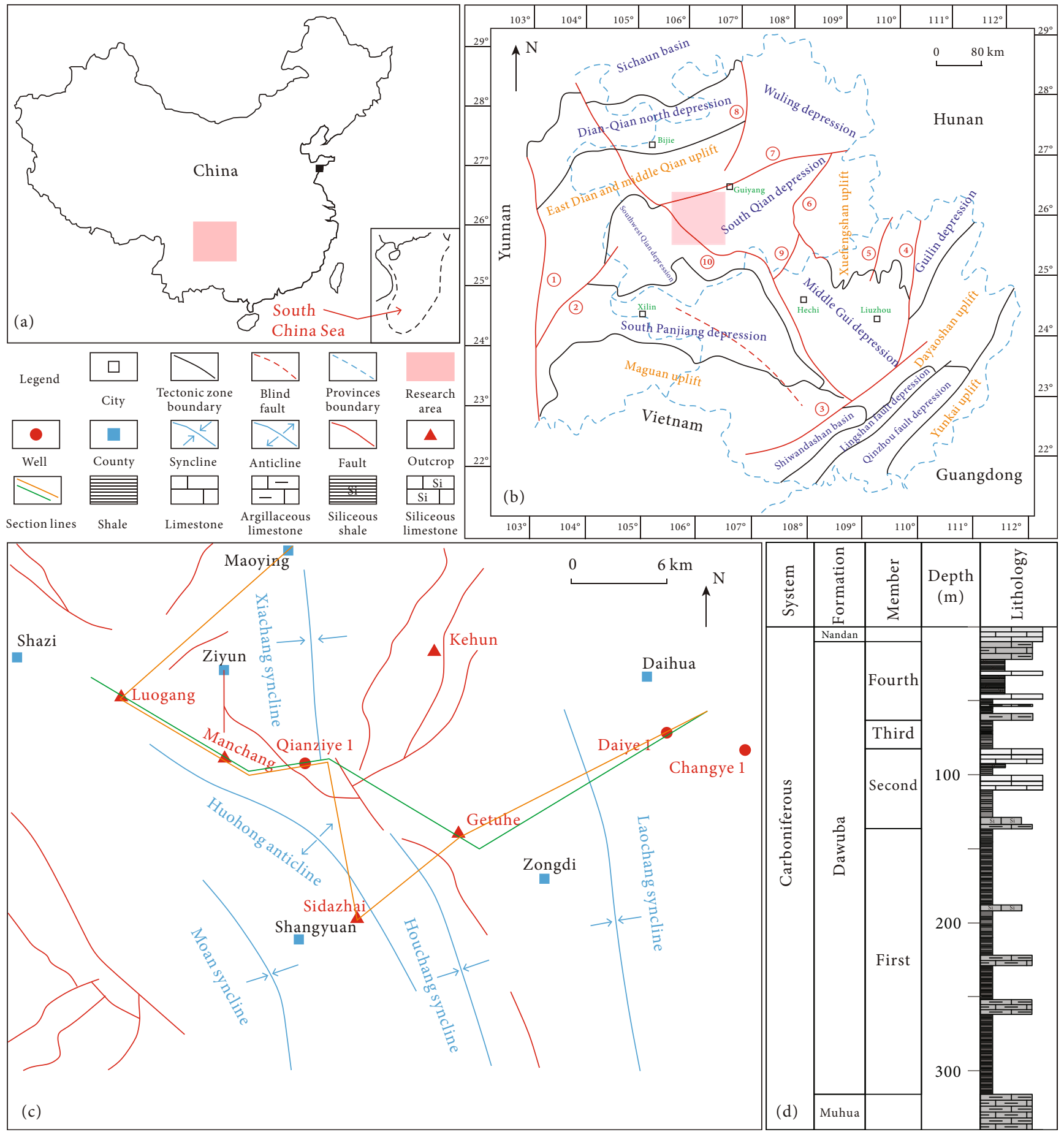

FIGURE 1: Location map of the research area (a, c, d), lithological characteristics of Dawuba Formation (b), tectonic characteristics of Ziyuan area (c), and location of samples from wells and outcrops (d). (1) Xiaojiang fault; (2) Shizong fault; (3) Pingxiang-Dali fault; (4) Yongfu fault; (5) Longsheng fault; (6) Tongren-Sandu fault; (7) Guiyang-Zhenyuan fault; (8) Zunyi fault; (9) Libo fault; (1) Ziyun-Luodian-Nandan-Duan fault. "Dian" means Yunnan province; "Qian" means Duizhou province; "Gui" means Guangxi province. The yellowish-brown section line crosses the wells and outcrops used in stratigraphic correlation and the green one used in comparison of total organic carbon (TOC).

However, the constant exploration and development of shale oil and gas in new areas is still necessary, because it still cannot meet the country's energy demand at the present stage. The Permian transitional facies shale is widely distributed in China, and only a few shale gas discoveries have been made in it of some areas [24-26]. Hence, the industry has dif- ferent opinions on whether the Permian transitional facies shale has commercial scale shale gas. In addition, the major breakthrough in Devonian and Carboniferous shale strata has not been made in south China. The main reason is that most areas in the south belonged to the paleogeographic environment alternative distribution of interplatform and 


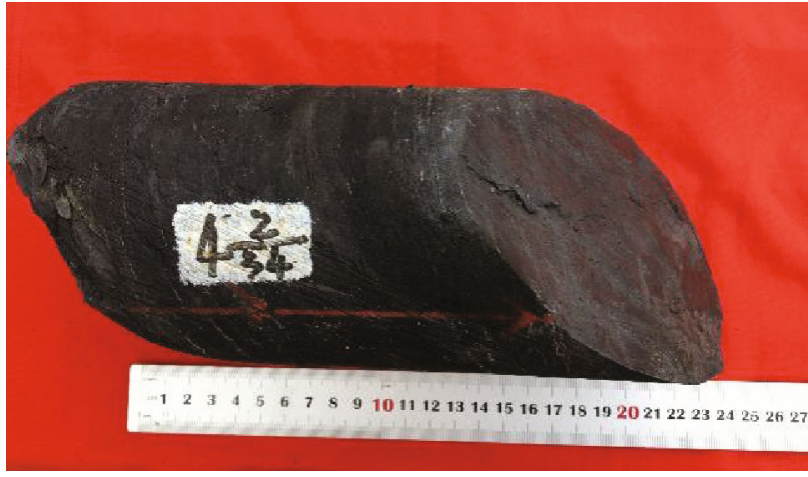

(a)

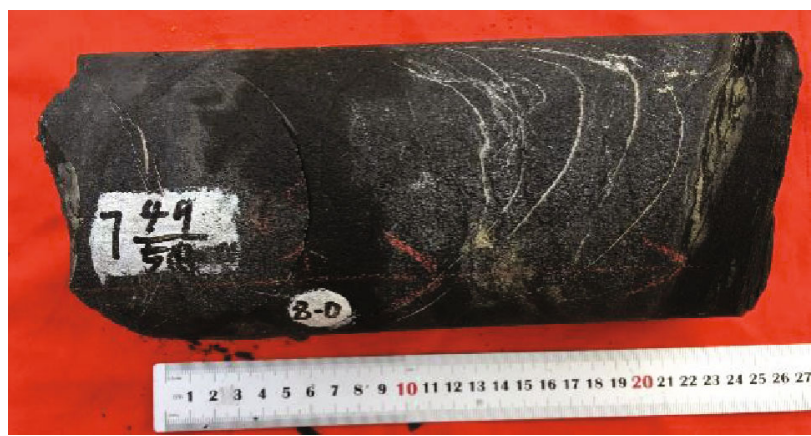

(c)

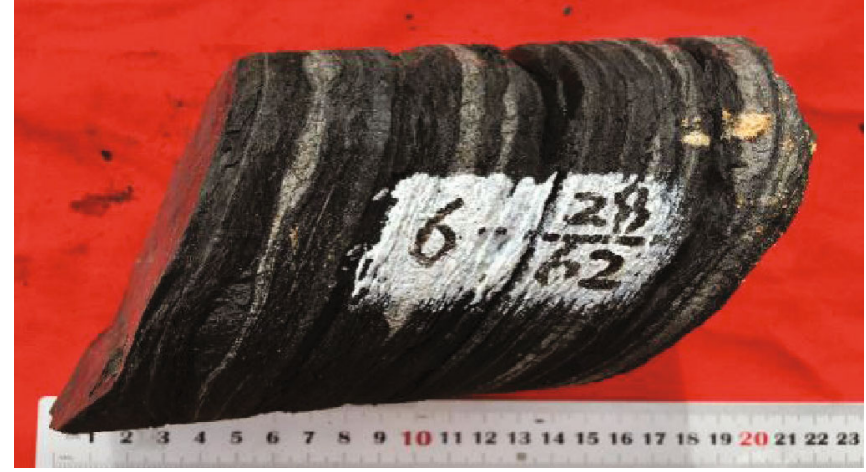

(b)

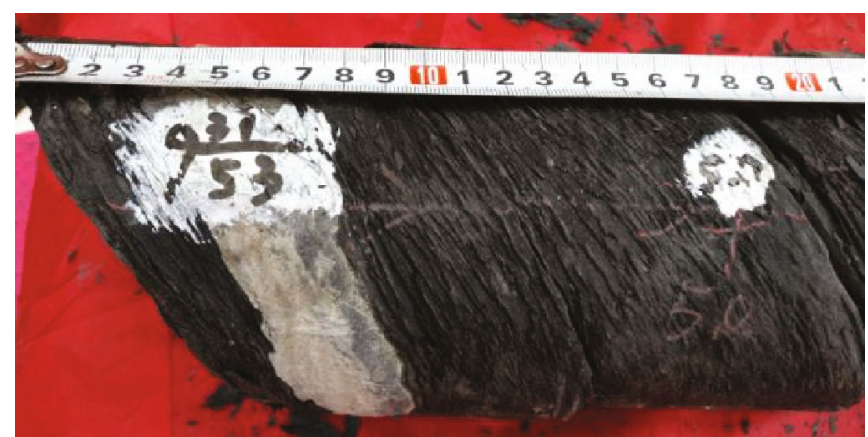

(d)

FIGURE 2: Images of shale samples from Dawuba Formation: (a) black shale sample from the fourth member of Dawuba Formation; (b) black shale with argillaceous stripe sample from the third member of Dawuba Formation; (c) black shale sample from the second member of Dawuba Formation; (d) black shale sample from the first member of Dawuba Formation.

basin during the Devonian-Carboniferous period [27]. Hence, the lithological association varies greatly, including the shale development thickness, distribution characteristics, organic geochemical characteristics, mineral composition, mechanical properties, and reservoir property of different layers [28].

In this paper, the Ziyun area of South Qian Depression is taken as the research area. Core samples of shale and mudstone in wells Qianziye 1, Changye 1, and Daiye 1, Guizhou, as well as samples collected from the surrounding outcrops, Manchang, Getuhe, Sidazhai, and Luogang, were taken as the research objects. The stratigraphic distribution characteristics, geochemical characteristics, reservoir characteristics, and gas bearing properties of Dawuba Formation were evaluated. On this basis, the sedimentary background and its effect on organic matter enrichment were discussed. Then, the favorable target layers for shale gas enrichment were optimized.

\section{Geological Setting}

The South Qian Depression is located in the southwest part of China (Figure 1(a)). It is a superimposed basin formed by the early Paleozoic Craton basin, the late Paleozoic passive continental margin basin, and the Mesozoic foreland basin [29-31]. The Guiyang-Zhenyuan fault zone and middle Qian uplift are the boundary in the northwest of the depression; the Tongren-Sandu fault zone and the Xuefengshan uplift are the boundary in the east and southeast; the Ziyun-Luodian fault zone is the boundary in the southwest of the depression (Figure 1(b)).

The study area is located in the west part of South Qian Depression and confined by the Ziyun and Guiyang fault. Under the tectonic processes of multiple stresses, the Carboniferous, Permian, and Triassic strata have undergone strong structural deformation and denudation of different extent. In the Indosinian-Yanshan and Himalayan stages, strong folds and thrust nappes resulted in massive shortening deformation. The north-south compressional deformation dominated throughout the entire district (Figure 1(c)). The anticline was in box shape with mainly Devonian and Carboniferous strata. The syncline was in a groove shape with the axis being mostly destroyed by strike compressional faults and mainly consists of Triassic strata. In some areas, it was covered in unconformity with the upper Cretaceous strata.

The Dawuba Formation is about $150-250 \mathrm{~m}$ thick and is mainly composed of shale, silty shale with thin chert layer, and a small amount of silty sandstone, generally containing iron and phosphorus nodules and spore fossils (Figures 1(d) and 2). According to the lithological characteristics of wells Qianziye 1, Daiye 1, and Changye 1, as well as outcrops Manchang, Getuhe, Sidazhai, Luogang, and Kehun, the Dawuba Formation can be divided into four members. 


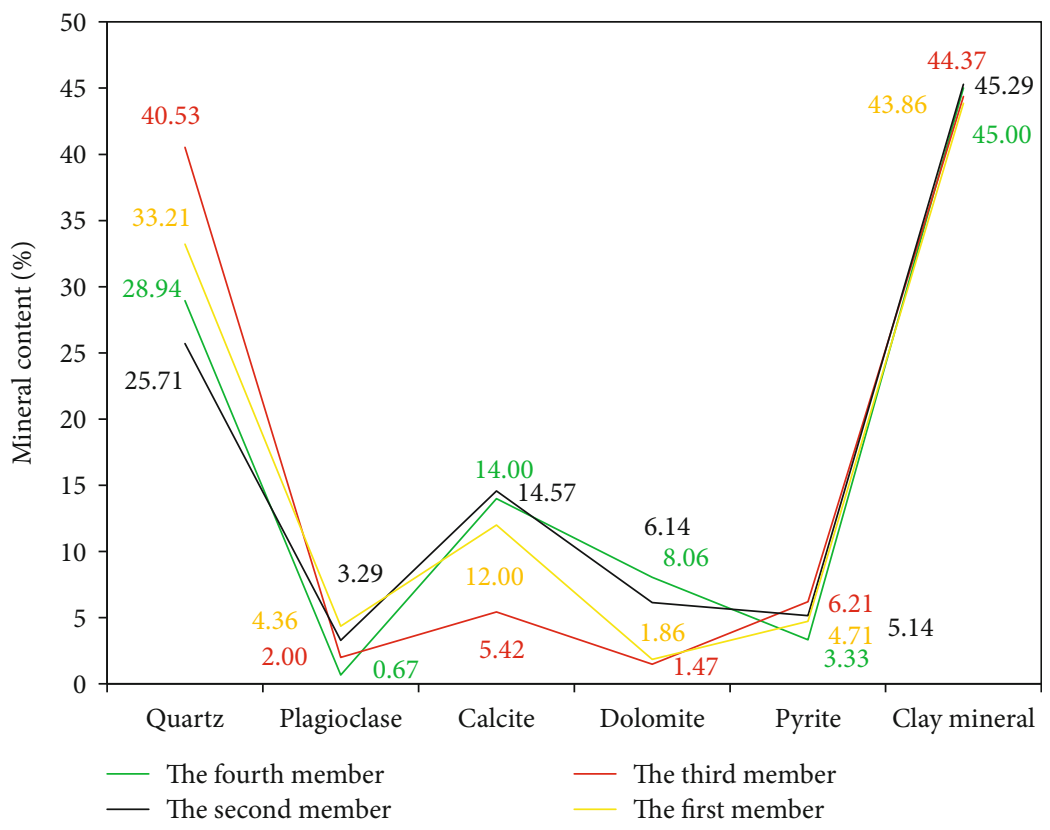

(a)

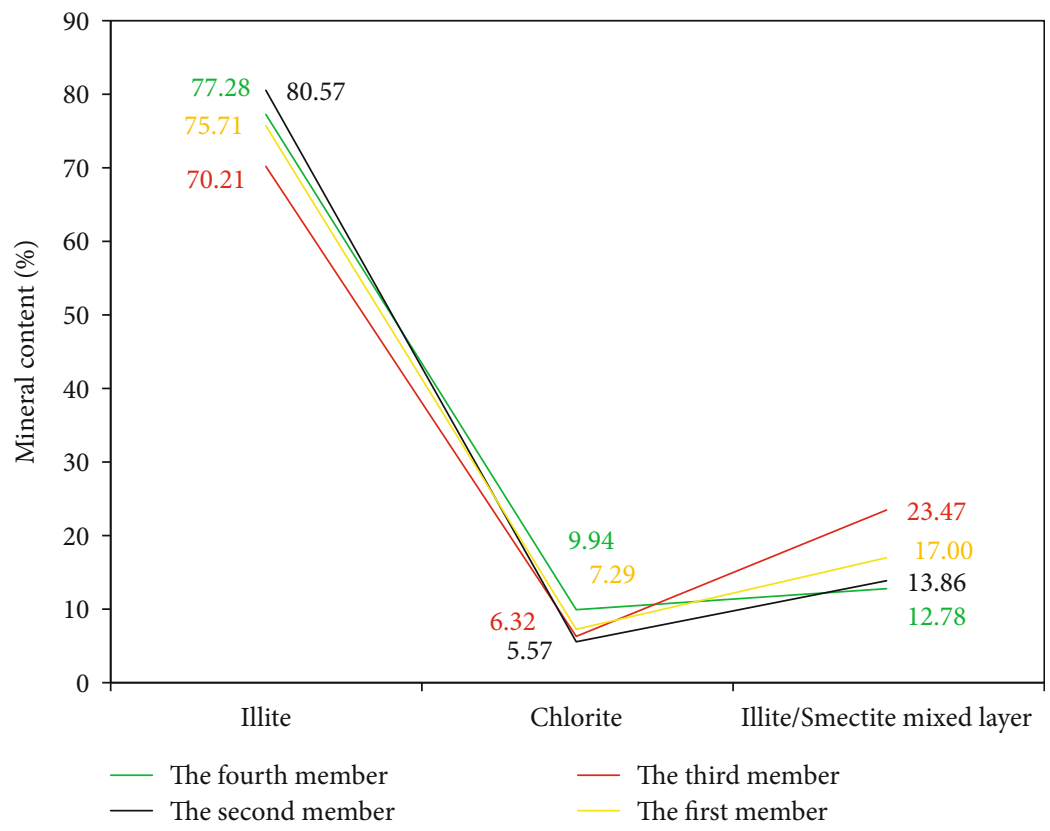

(b)

Figure 3: Mineral composition of the Dawuba Formation shale samples: (a) mineral composition of bulk-rock; (b) clay mineral composition.

The fourth member of Dawuba Formation is approximate $100 \mathrm{~m}$ thick and lithologically composed of dark shale, black mudstone, and gray mudstone sandwiched with dark gray marl limestone and gray limestone (Figure 2(a)). The third member of the Dawuba Formation is $30 \mathrm{~m}$ thick and lithologically consists of black shale, gray mudstone with dark gray marl limestone, and gray dolomitic siltstone (Figure 2(b)). The second member is $75 \mathrm{~m}$ thick and lithologically interbedded with dark gray marl and gray dolomite (Figure 2(c)). The first section of Dawuba Formation is about $150 \mathrm{~m}$ thick and lithologically composed of dark shale, gray black mudstone, and gray limestone (Figures 1(d) and 2(d)).

\section{Sample Preparation and Methods}

3.1. Lithology Analysis. Core observation and descriptions, including composition, texture, sedimentary structure, grain size, and color, were conducted to determine the lithofacies in Dawuba Formation. The mineral composition was measured by a Rigaku automated powder diffractometer (D/MAX-RA) equipped with a $\mathrm{Cu} X$-ray source $(40 \mathrm{kV}$, $35 \mathrm{~mA}$ ). The samples from Dawuba shale were analyzed for whole-bulk and clay fraction mineralogy by quantitative Xray diffraction following two independent processes. First, the bulk mineral composition of the powder sample was 


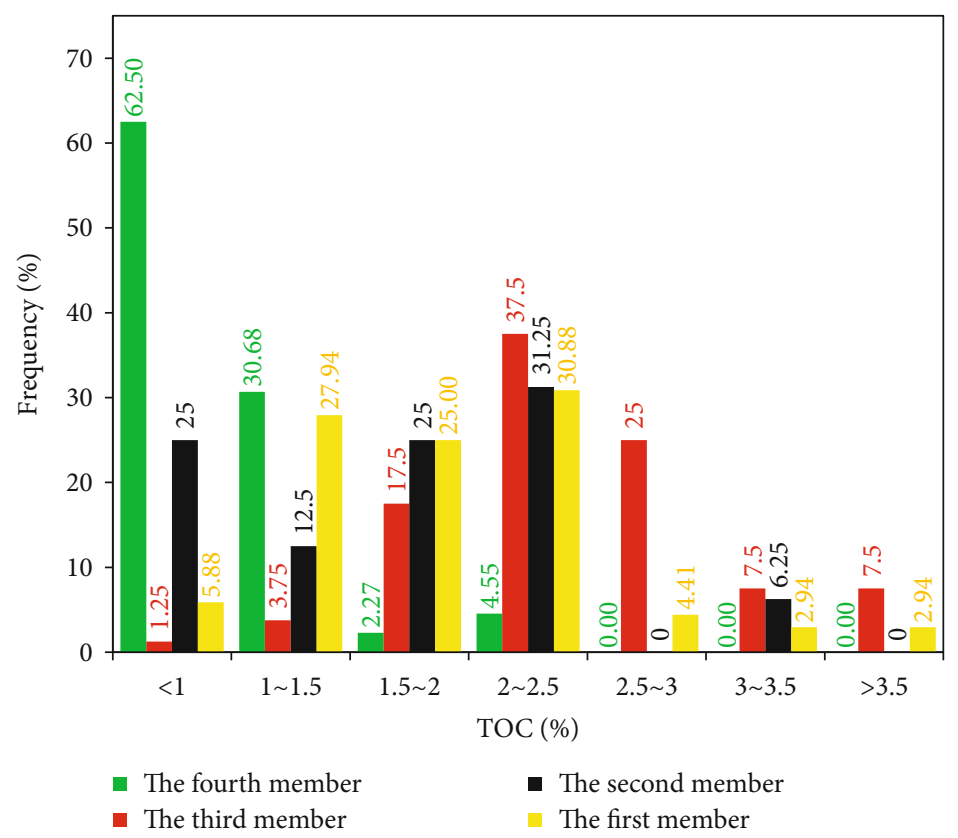

(a)

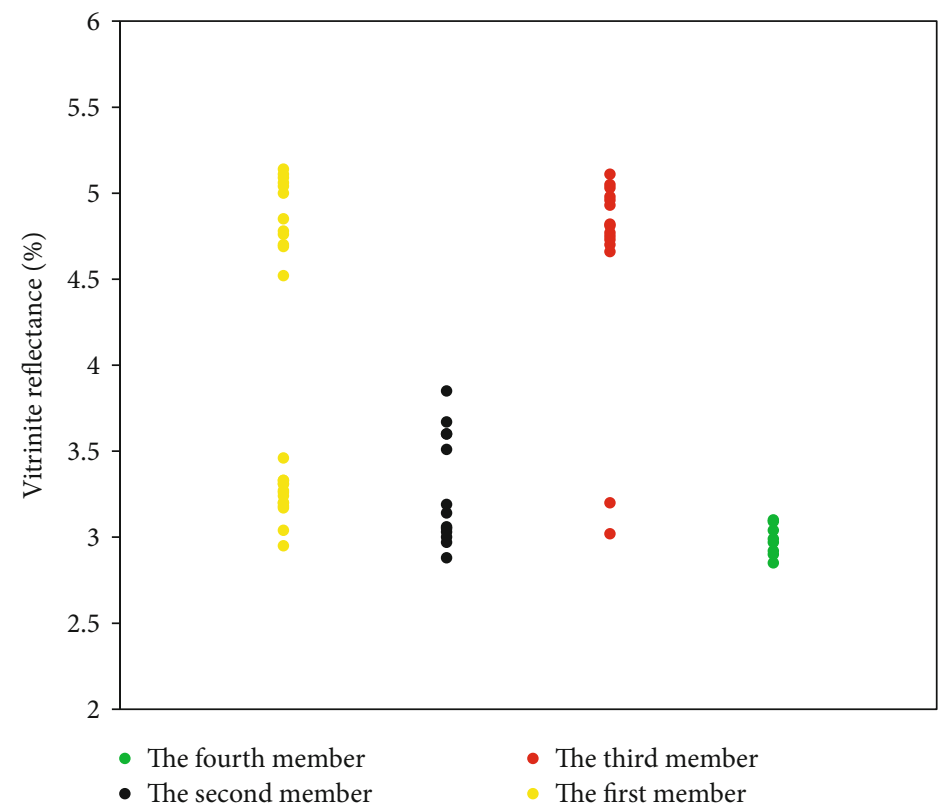

(b)

FIgURE 4: Histogram of TOC and $R_{o}$ of all the Dawuba Formation shale samples: (a) histogram of TOC; (b) $R_{o}$ value scope.

determined at this stage to only include the total clay content. The whole-rock samples were analyzed over an angular range of 4 to $70^{\circ} 2 \theta$ at a scanning speed of $1^{\circ} 2 \theta / \mathrm{min}$. Second, the individual clay mineral content of the clay fractions separated from the rock powder sample was determined. The clay minerals were analyzed over an angular range of 3 to $65^{\circ} 2 \theta$ at a scanning speed of $1.5^{\circ} 2 \theta / \mathrm{min}$. Quantification of the minerals was based on calculations of the integrated area using the Jade Five software.

3.2. Analysis of Geochemical Characteristics. The total organic carbon (TOC) analyses were conducted using labora- tory apparatus Leco TOC (CS-230HC). The samples were immersed in $10 \% \mathrm{HCl}$ solution for two days to remove the carbonate minerals and then washed with distilled water. Before measurement, the samples were dried in a stoving oven at $65^{\circ} \mathrm{C}$ for 1.5 days. The thermal maturity reflected by the experimental vitrinite reflectance $\left(R_{o}\right)$ values and maceral composition of Dawuba Formation shale samples were acquired by using an oil-immersion lens and a fullautomatic microscope photometer (a Leica MPV Compact II reflected-light microscope) in both reflected and fluorescent modes. Before the measurements, the equipment calibration was performed using two standard samples of 
TABLE 1: The maceral composition of all the Dawuba Formation shale samples.

\begin{tabular}{|c|c|c|c|c|c|c|c|c|c|c|c|c|}
\hline \multirow{2}{*}{$\begin{array}{l}\text { Sample } \\
\text { ID }\end{array}$} & \multirow{2}{*}{ Depth/m } & \multirow{2}{*}{ Member } & \multirow{2}{*}{ Lithology } & \multirow{2}{*}{$\begin{array}{c}\text { Sapropelinite } \\
\%\end{array}$} & \multicolumn{4}{|c|}{ Exinite \% } & \multirow{2}{*}{$\begin{array}{c}\text { Vitrinite } \\
\% \\
\text { Normal } \\
\text { vitrinite }\end{array}$} & \multirow{2}{*}{$\begin{array}{c}\text { Inertinite } \\
\quad \% \\
\text { Fusinite }\end{array}$} & \multicolumn{2}{|c|}{$\begin{array}{c}\text { Types } \\
\text { classification }\end{array}$} \\
\hline & & & & & Resinite & Homocollinite & Alginite & Sum & & & Index & Type \\
\hline CY1-1 & 751 & Fourth & $\begin{array}{l}\text { Black } \\
\text { shale }\end{array}$ & 0 & - & 59 & 28 & 87 & 10 & 3 & 33 & $\mathrm{II}_{2}$ \\
\hline DY1-5 & 450 & Fourth & $\begin{array}{l}\text { Black } \\
\text { shale }\end{array}$ & 0 & 2 & 63 & 20 & 85 & 13 & 2 & 30.8 & $\mathrm{II}_{2}$ \\
\hline MC-1 & 2750 & Fourth & $\begin{array}{l}\text { Black } \\
\text { shale }\end{array}$ & 0 & - & 63 & 22 & 85 & 12 & 3 & 30.5 & $\mathrm{II}_{2}$ \\
\hline ZY1-1 & 2668 & Fourth & $\begin{array}{l}\text { Black } \\
\text { shale }\end{array}$ & 0 & 2 & 67 & 13 & 82 & 14 & 4 & 26.5 & $\mathrm{II}_{2}$ \\
\hline ZY1-3 & 2688 & Fourth & $\begin{array}{l}\text { Black } \\
\text { shale }\end{array}$ & 0 & 4 & 56 & 18 & 78 & 17 & 5 & 21.3 & $\mathrm{II}_{2}$ \\
\hline ZY1-4 & 2759 & Fourth & $\begin{array}{l}\text { Black } \\
\text { shale }\end{array}$ & 0 & 3 & 56 & 17 & 76 & 16 & 8 & 18 & $\mathrm{II}_{2}$ \\
\hline ZY1-9 & 2738 & Fourth & $\begin{array}{l}\text { Black } \\
\text { shale }\end{array}$ & 0 & - & 64 & 17 & 81 & 16 & 3 & 25.5 & $\mathrm{II}_{2}$ \\
\hline GTH-1 & Outcrop & Third & $\begin{array}{l}\text { Black } \\
\text { shale }\end{array}$ & 0 & 5 & 47 & 24 & 76 & 18 & 6 & 18.5 & $\mathrm{II}_{2}$ \\
\hline LG-1 & Outcrop & Third & $\begin{array}{l}\text { Black } \\
\text { shale }\end{array}$ & 0 & - & 58 & 26 & 84 & 11 & 5 & 28.8 & $\mathrm{II}_{2}$ \\
\hline ZY1-2 & 2806.50 & Third & $\begin{array}{l}\text { Black } \\
\text { shale }\end{array}$ & 0 & - & 72 & 13 & 85 & 11 & 4 & 30.3 & $\mathrm{II}_{2}$ \\
\hline ZY1-6 & 2796 & Third & $\begin{array}{l}\text { Black } \\
\text { shale }\end{array}$ & 0 & 0 & 74 & 12 & 86 & 13 & 1 & 32.3 & $\mathrm{II}_{2}$ \\
\hline ZY1-7 & 2802.60 & Third & $\begin{array}{l}\text { Black } \\
\text { shale }\end{array}$ & 0 & - & 73 & 11 & 84 & 14 & 2 & 29.5 & $\mathrm{II}_{2}$ \\
\hline ZY1-8 & 2812.5 & Third & $\begin{array}{l}\text { Black } \\
\text { shale }\end{array}$ & 0 & - & 64 & 15 & 79 & 16 & 5 & 22.5 & $\mathrm{II}_{2}$ \\
\hline GTH-2 & Outcrop & Second & $\begin{array}{l}\text { Black } \\
\text { shale }\end{array}$ & 0 & 0 & 55 & 26 & 81 & 16 & 3 & 31.8 & $\mathrm{II}_{2}$ \\
\hline LG-2 & Outcrop & Second & $\begin{array}{l}\text { Black } \\
\text { shale }\end{array}$ & 0 & 1 & 53 & 29 & 83 & 14 & 3 & 31.8 & $\mathrm{II}_{2}$ \\
\hline ZY1-10 & 2857 & Second & $\begin{array}{l}\text { Black } \\
\text { shale }\end{array}$ & 0 & 0 & 54 & 28 & 82 & 15 & 3 & 31.8 & $\mathrm{II}_{2}$ \\
\hline ZY1-12 & 2858 & Second & $\begin{array}{l}\text { Black } \\
\text { shale }\end{array}$ & 0 & 4 & 53 & 29 & 86 & 11 & 3 & 31.8 & $\mathrm{II}_{2}$ \\
\hline ZY1-13 & 2858.5 & Second & $\begin{array}{l}\text { Black } \\
\text { shale }\end{array}$ & 0 & 0 & 50 & 28 & 78 & 17 & 5 & 31.8 & $\mathrm{II}_{2}$ \\
\hline CY1-2 & 880 & First & $\begin{array}{l}\text { Black } \\
\text { shale }\end{array}$ & 0 & 4 & 57 & 14 & 75 & 17 & 8 & 16.8 & $\mathrm{II}_{2}$ \\
\hline CY1-3 & 881 & First & $\begin{array}{l}\text { Black } \\
\text { shale }\end{array}$ & 0 & 4 & 59 & 8 & 71 & 22 & 7 & 12 & $\mathrm{II}_{2}$ \\
\hline DY1-1 & 633 & First & $\begin{array}{l}\text { Black } \\
\text { shale }\end{array}$ & 0 & 0 & 62 & 22 & 84 & 12 & 4 & 29 & $\mathrm{II}_{2}$ \\
\hline DY1-2 & 634 & First & $\begin{array}{l}\text { Black } \\
\text { shale }\end{array}$ & 0 & - & 74 & 16 & 90 & 8 & 2 & 37 & $\mathrm{II}_{2}$ \\
\hline $\mathrm{KH}-1$ & Outcrop & First & $\begin{array}{l}\text { Black } \\
\text { shale }\end{array}$ & 0 & - & 69 & 16 & 85 & 11 & 4 & 30.3 & $\mathrm{II}_{2}$ \\
\hline SDZ-1 & Outcrop & First & $\begin{array}{l}\text { Black } \\
\text { shale }\end{array}$ & 0 & 0 & 75 & 12 & 87 & 11 & 2 & 33.3 & $\mathrm{II}_{2}$ \\
\hline SDZ-2 & Outcrop & First & $\begin{array}{l}\text { Black } \\
\text { shale }\end{array}$ & 0 & - & 80 & 12 & 92 & 6 & 2 & 39.5 & $\mathrm{II}_{2}$ \\
\hline
\end{tabular}


TABle 1: Continued.

\begin{tabular}{|c|c|c|c|c|c|c|c|c|c|c|c|c|}
\hline \multirow{2}{*}{$\begin{array}{l}\text { Sample } \\
\text { ID }\end{array}$} & \multirow{2}{*}{ Depth/m } & \multirow{2}{*}{ Member } & \multirow{2}{*}{ Lithology } & \multirow{2}{*}{$\begin{array}{c}\text { Sapropelinite } \\
\%\end{array}$} & \multicolumn{4}{|c|}{ Exinite \% } & \multirow{2}{*}{$\begin{array}{c}\text { Vitrinite } \\
\% \\
\text { Normal } \\
\text { vitrinite }\end{array}$} & \multirow{2}{*}{$\begin{array}{c}\text { Inertinite } \\
\quad \% \\
\text { Fusinite }\end{array}$} & \multicolumn{2}{|c|}{$\begin{array}{c}\text { Types } \\
\text { classification }\end{array}$} \\
\hline & & & & & Resinite & Homocollinite & Alginite & Sum & & & Index & Type \\
\hline ZY1-14 & 2871 & First & $\begin{array}{l}\text { Black } \\
\text { shale }\end{array}$ & 0 & - & 65 & 20 & 85 & 12 & 3 & 30.5 & $\mathrm{II}_{2}$ \\
\hline ZY1-15 & 2877.40 & First & $\begin{array}{l}\text { Black } \\
\text { shale }\end{array}$ & 0 & - & 63 & 19 & 82 & 14 & 4 & 26.5 & $\mathrm{II}_{2}$ \\
\hline ZY1-16 & 2931.95 & First & $\begin{array}{l}\text { Black } \\
\text { shale }\end{array}$ & 0 & 5 & 61 & 14 & 80 & 15 & 5 & 23.8 & $\mathrm{II}_{2}$ \\
\hline ZY1-17 & 2882.50 & First & $\begin{array}{l}\text { Black } \\
\text { shale }\end{array}$ & 0 & - & 76 & 16 & 92 & 5 & 3 & 39.3 & $\mathrm{II}_{2}$ \\
\hline
\end{tabular}

known reflectance. Each $R_{o}$ represents the average of 20-30 measuring points. Each maceral analysis covered more than 30 points.

3.3. SEM Observation. Scanning electron microscopy (SEM) was performed to provide visualization of the minerals and micropores through FEI Quanta-200F apparatus with an energy-dispersive spectrometer (EDS). Fractured surfaces generated from slightly knock with a little hammer were used in SEM observation. Ar-ion polishing was applied in SEM observation. A thin layer of Au element was applied in gilding on the fractured surfaces before observation. The operating current must be maintained to be $15 \mathrm{kV}$ for stable signal output of clear images.

3.4. Porosity and Permeability Analysis. The porosity of the dry samples was determined from the grain density obtained from helium pycnometry (skeletal density), and the bulk volume of the plugs was calculated from mercury immersion (bulk density) [32]. The total porosity was calculated from the difference between the bulk and skeletal densities. The permeability was calculated from measurements with helium expansion at a constant temperature of $30^{\circ} \mathrm{C}$ and a range of pressures from $5 \mathrm{MPa}$ to $30 \mathrm{MPa}$ in a stepwise increase [33, 34]. The cylinder samples of shale with diameters of $2.5 \mathrm{~cm}$ and lengths of $5 \mathrm{~cm}$ were analyzed for porosity and permeability. These 25 samples had no factitious fractures on the surface formed. But, it is hard to identify artificial microfractures that formed interior the sample, which explains the aberrant data points of porosity and permeability analysis.

3.5. Gas Content and Component Analysis. The shale gas was collected through gas gathering system, of which the principle was water gas displacing method. The water in it is saturated salt solution. When the core sample was taken out from the drilling borehole, they were put in an air collector as soon as possible. The shale gas gathered during the unheated stage was regarded as desorbed gas. When the desorbed gas content did not increase any more, the system was heated, and the gas gathered was regarded as residual gas. The shale gas component was determined through gas chromatographic method.
3.6. Element Analysis. Trace element analysis can also be used in the study of the sedimentary environment, such as the reducibility or oxidability, salinity, and climate [35-39]. The shale samples of Dawuba Formation were used for the element analysis, which was determined with a laserablation microprobe linked to an inductively coupled plasma mass spectrometer (LAM-ICP-MS) at the Beijing Research Institute of Uranium Geology.

\section{Results}

4.1. Mineral Composition Characteristics. The Dawuba Formation shale is mainly composed of quartz and clay minerals (Figure 3). The third member shale exhibited the highest content of quartz (average 40.53\%) but the lowest content of calcite (average 5.42\%) (Figure 3(a)). For the shale of other three members, quartz was the dominated brittle minerals and then followed by calcite (Figure 3(a)). The contents of plagioclase, dolomite, and pyrite of all the four members were smaller than $10 \%$ (Figure 3(a)). The clay minerals were not much difference in content in shale of the four members. The clay minerals were mainly composed of illite, which reached larger than $70 \%$, followed by illite/smectite mixed layers (average $16.78 \%$ ) and chlorite $(<10 \%)$ (Figure $3(\mathrm{~b})$ ). From the perspective of clay mineral composition, the shale of the four members in Dawuba Formation was similar to each other. Among the shale samples of Dawuba Formation, the third member shale exhibited the highest content of illite/smectite mixed layers (average 23.47\%) but the lowest content of illite (average 70.21\%) (Figure 3(b)).

4.2. Organic Matter Characteristics. The TOC content of all the samples varies from $0.26 \%$ to $4.66 \%$, while most samples are included in the range of $1-3 \%$ (Figure 4 ). Shale samples from the fourth member showed the lowest content of TOC values, while the TOC values did not show substantial difference among the shale sample from the other three members. Some shale samples in the third member show toc content larger than 3\% (Figure 4). The measured vitrinite reflectance $\left(R_{o}\right)$ of all the Dawuba Formation shale samples is in the range of $2.85-5.14 \%$ (Figure 4 ). The measured $R_{o}$ of most of the samples from all the four members ranged from 


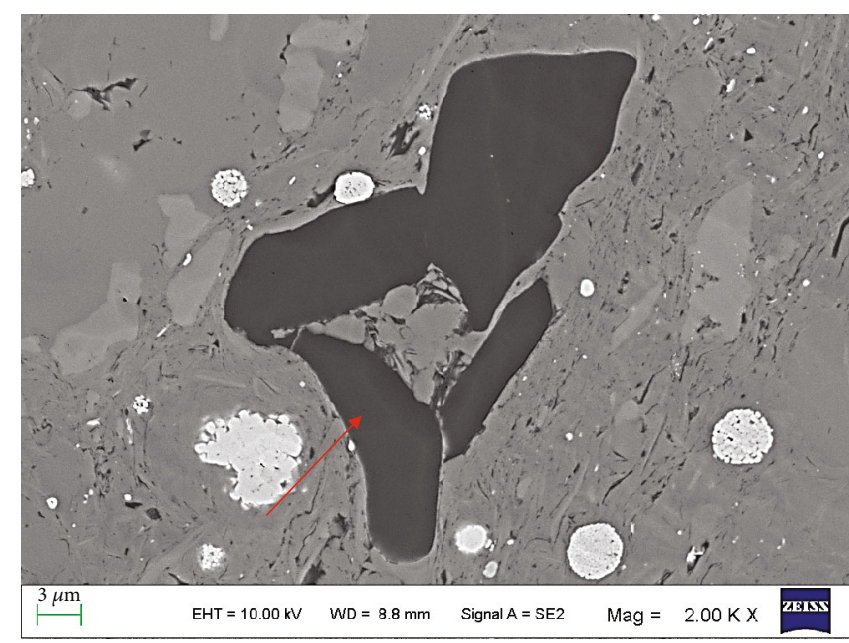

(a)

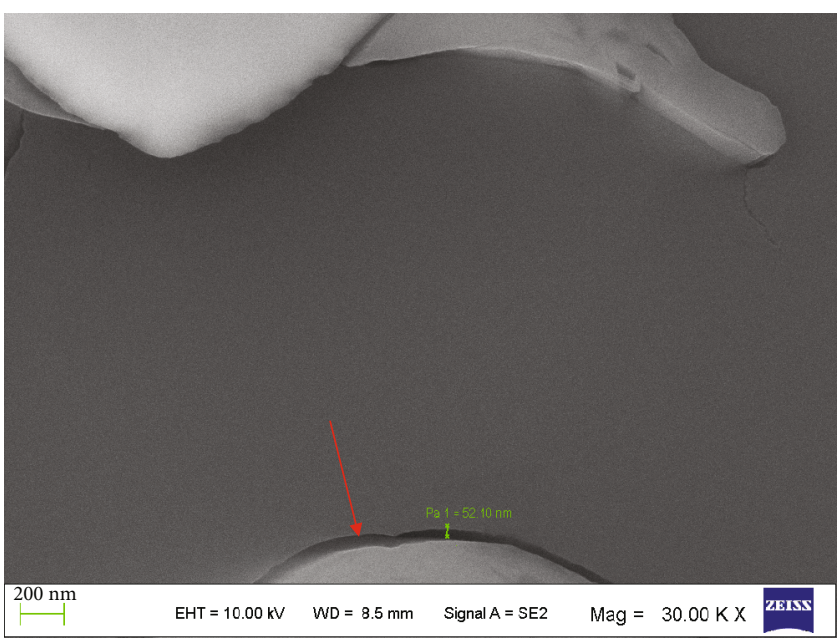

(c)

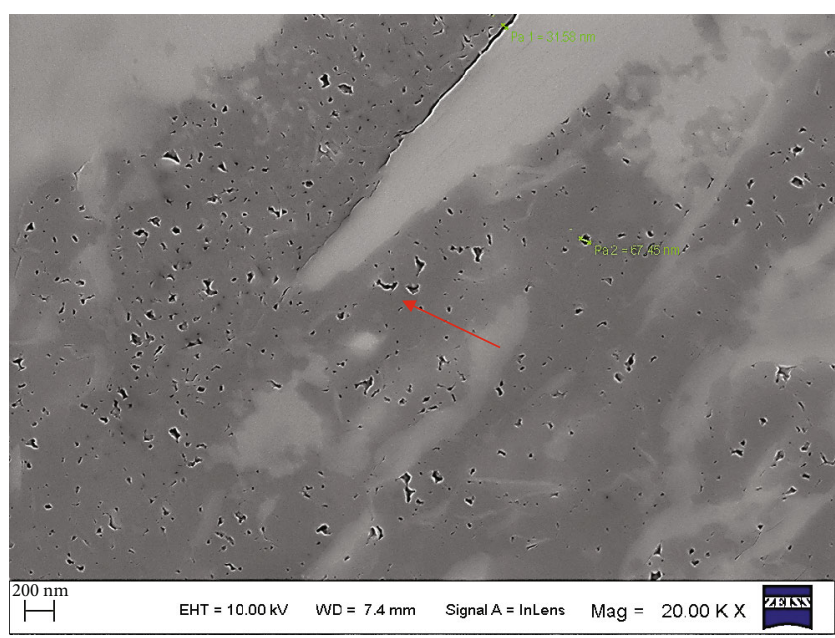

(e)

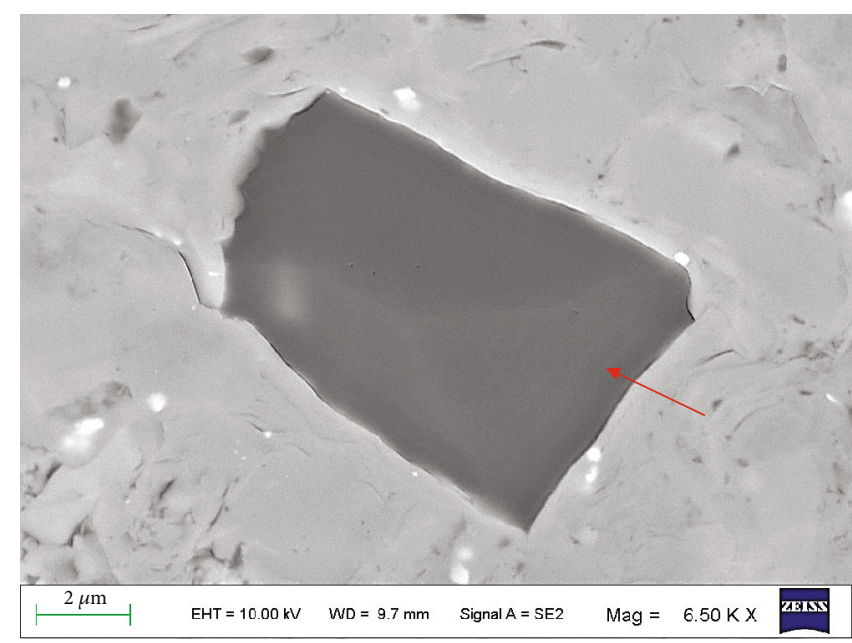

(b)

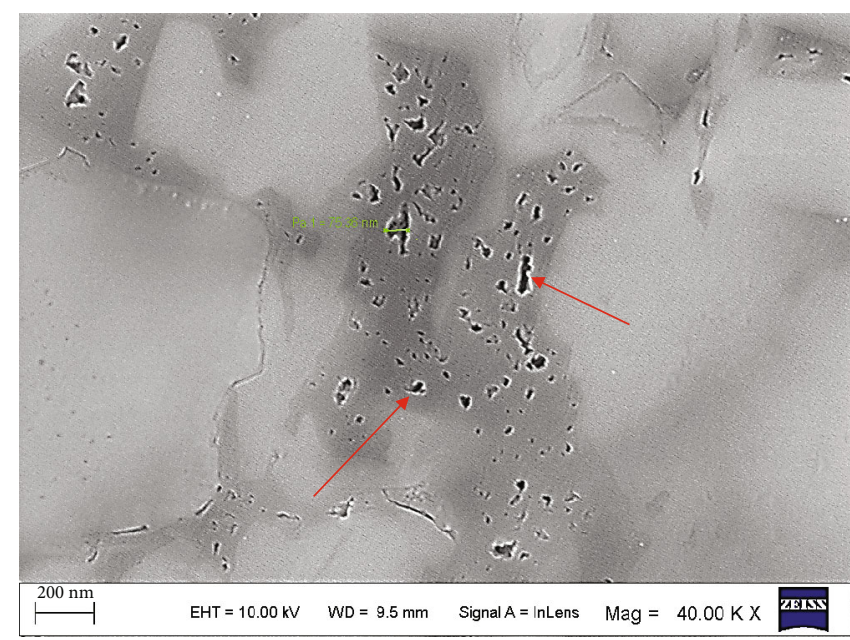

(d)

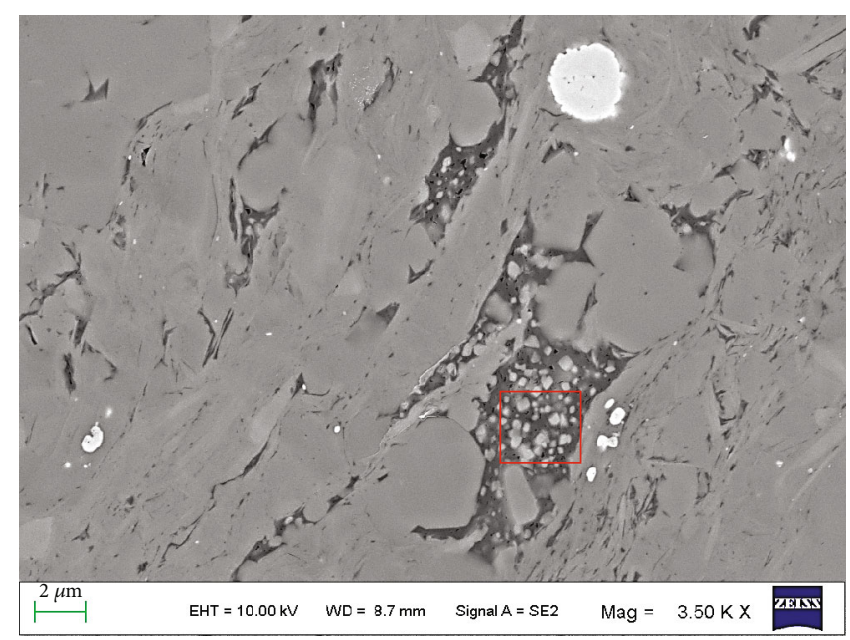

(f)

Figure 5: Continued. 


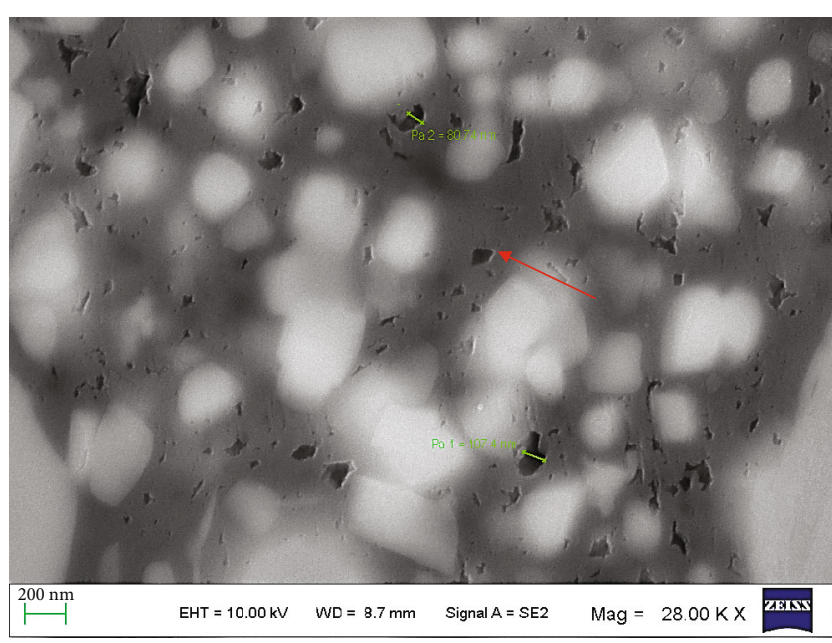

(g)

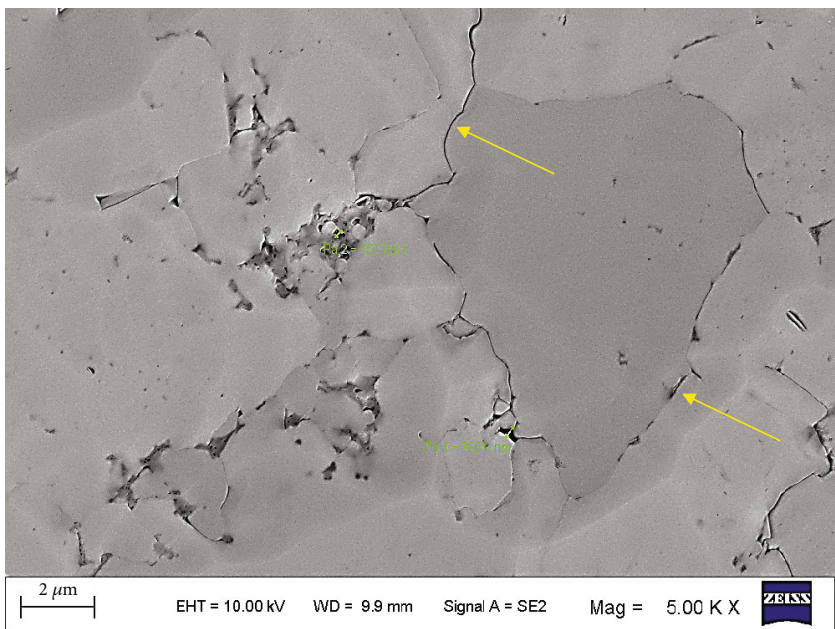

(i)

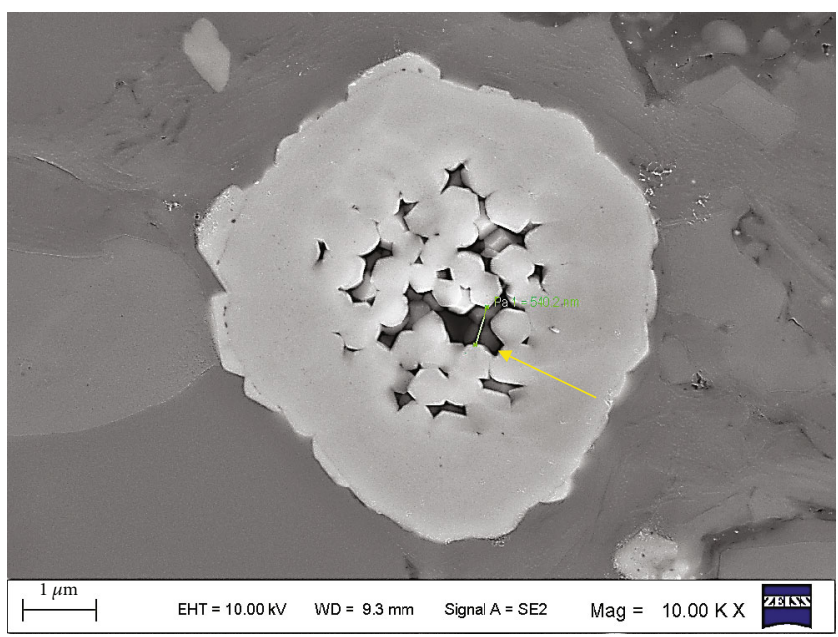

(k)

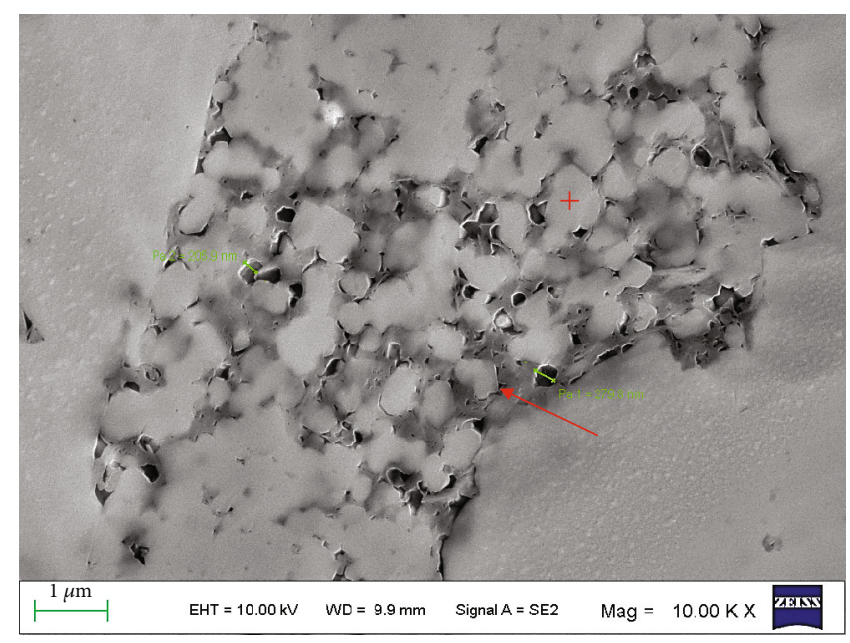

(h)

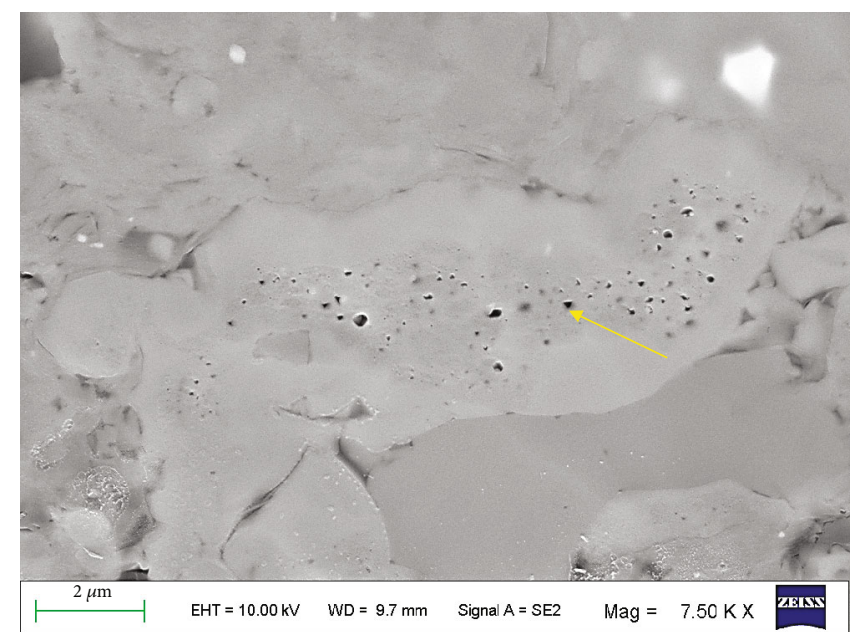

(j)

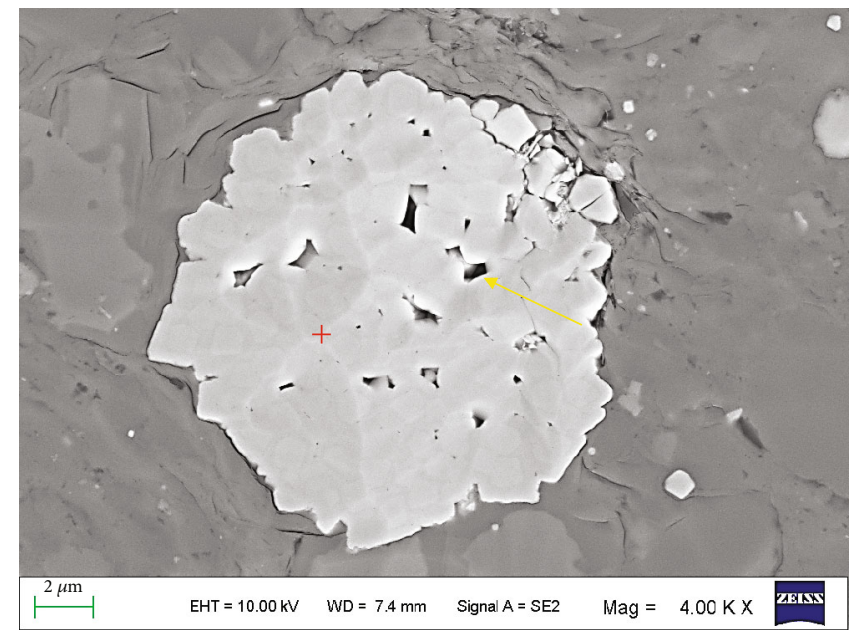

(1)

Figure 5: Continued. 


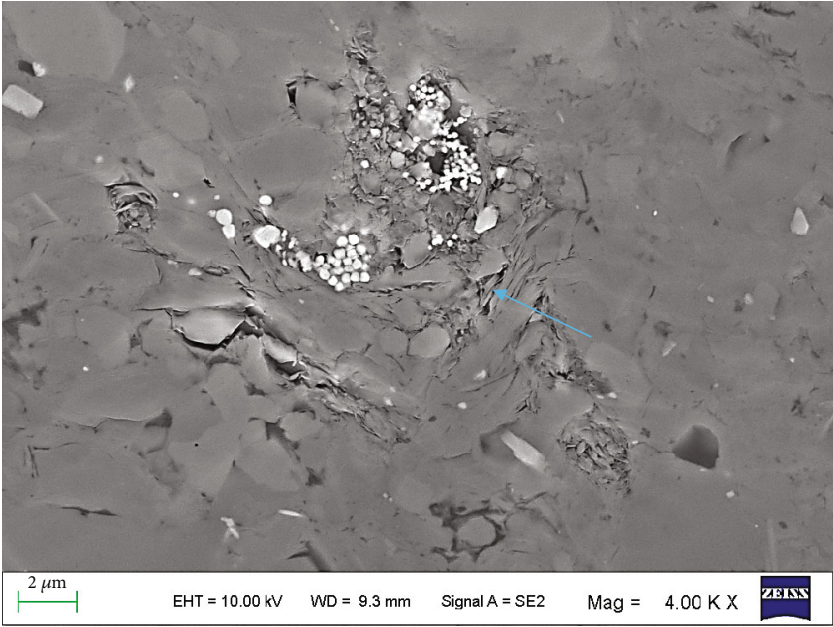

$(\mathrm{m})$

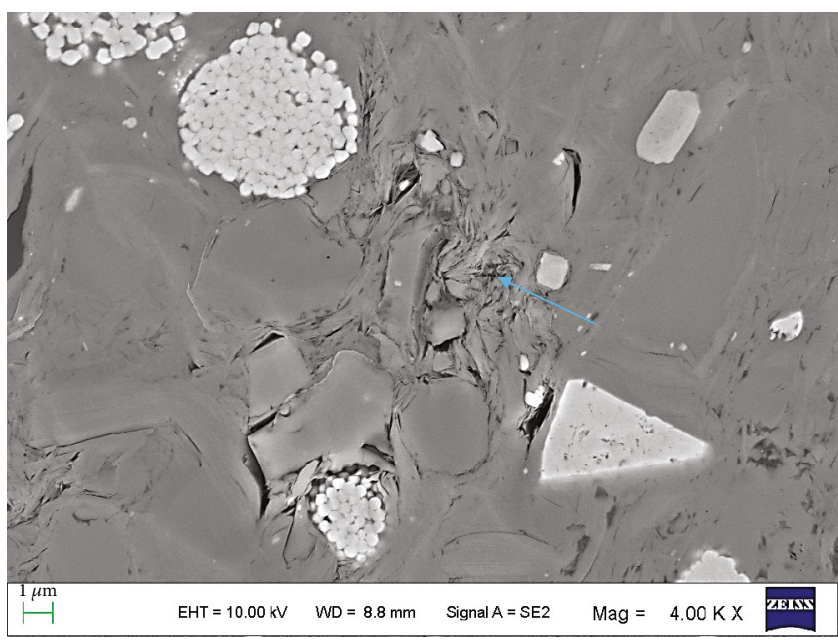

(o)

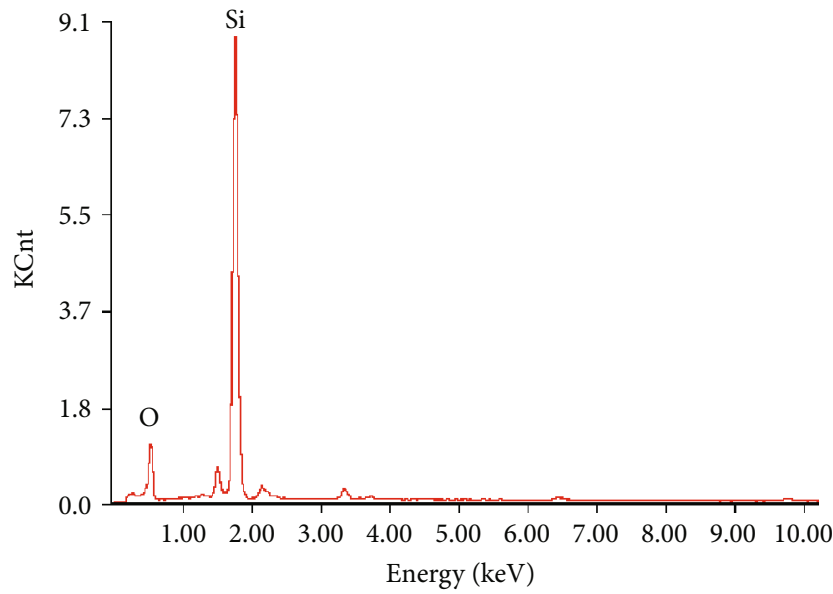

(q)

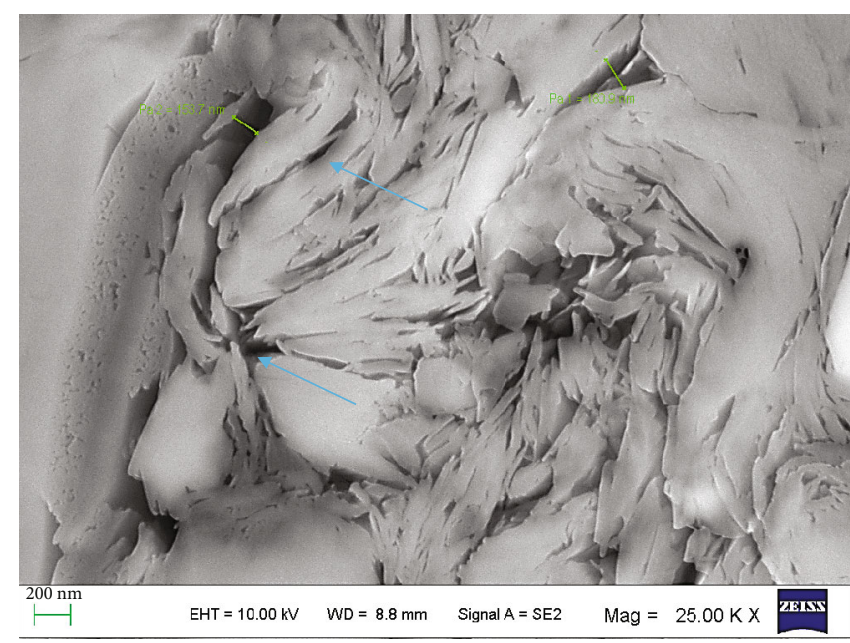

(n)

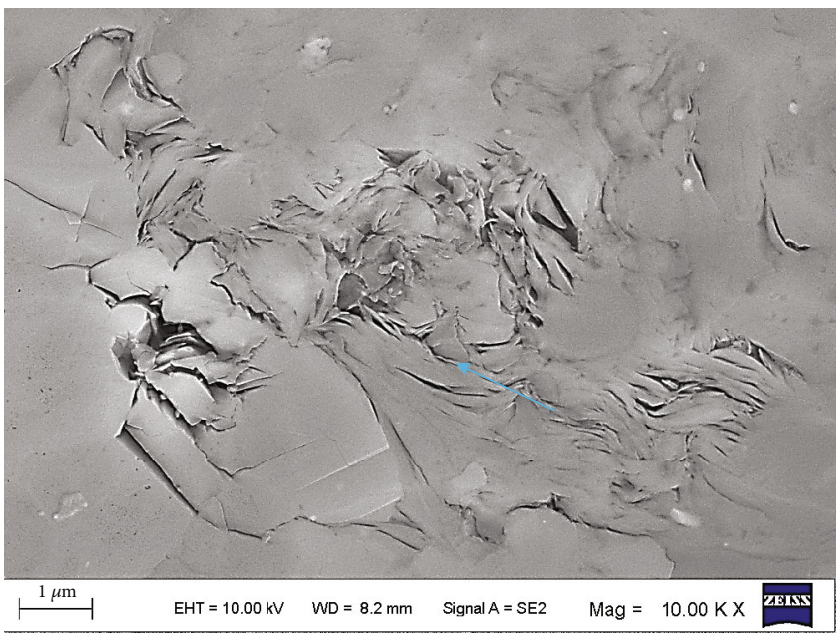

(p)

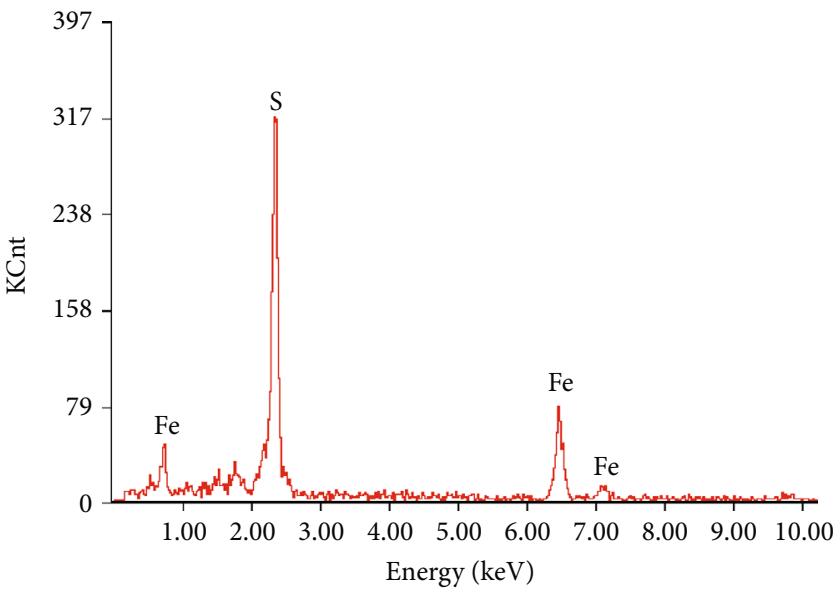

$(\mathrm{r})$

FIGURE 5: Images of SEM observation for the Dawuba Formation shale. The red arrows point to the organic matter and organic matter pores. The yellow arrows point to the pores related to quartz and pyrite. The blue arrows point to the pores among clay minerals. (a) $2946 \mathrm{~m}$, the $1 \mathrm{st}$ member, black shale; (b, j) $2929 \mathrm{~m}$, the 1 st member, black shale; (c) $2811.5 \mathrm{~m}$, the 4th member, black shale; (d) $2942.15 \mathrm{~m}$, the $1 \mathrm{st}$ member, black shale; (e) $2950 \mathrm{~m}$, the 1st member, black shale; (f, g) $2946.6 \mathrm{~m}$, the 1st member, black shale; (h, i) $2983.3 \mathrm{~m}$, the 1 st member, black shale; (k, m) $2950.1 \mathrm{~m}$, the 1st member, black shale; (l) $2932.95 \mathrm{~m}$, the 1 st member, black shale; (n, o) $2946.6 \mathrm{~m}$, the 1 st member, black shale; (p) $2883.5 \mathrm{~m}$, the 2nd member, black shale; (q) EDS spectrum of red “+” in image (h); (r) EDS spectrum of red “+” in image (l). 


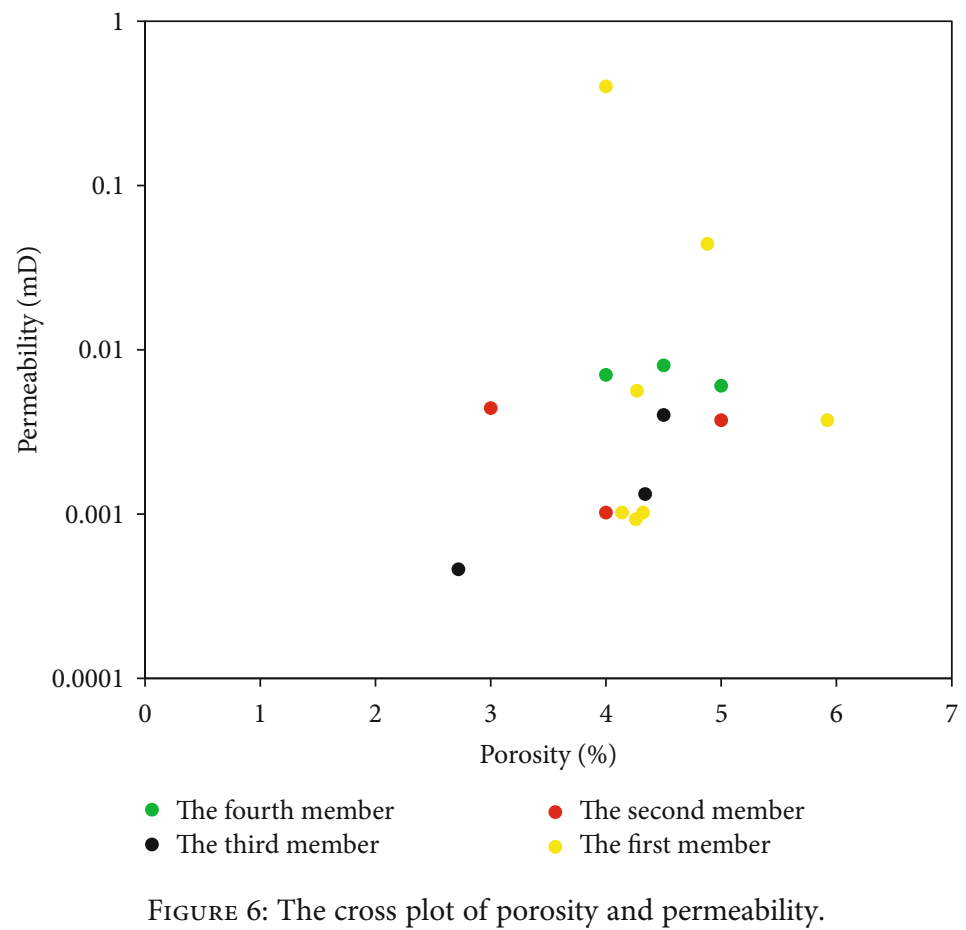

$2.85 \%$ to $4.0 \%$, which means most of Dawuba Formation shale samples were in the gas-generation stage at the present time. But some $R_{o}$ values of shale samples from the first and third members were larger than $4.5 \%$ (Figure 4 ), which means overmaturity stage. It was speculated that the high $R_{o}$ was caused by magmatic hydrothermal deposit, but there was no precise evidence. Approaching to the organic matter type from the point of view of maceral composition, exinite dominated the shale samples of Dawuba Formation, which means an incline to Type $\mathrm{II}_{2}$ organic matter (Table 1 ). The exinite mainly consisted of homocollinite and alginite (Table 1). The vitrinite and inertinite were not widely developed. In general, the organic matter type did not show material difference among the shale samples from the four members (Table 1).

4.3. Characterization of Pores. Compared with marine shale, organic matter pores did not hugely develop in Dawuba Formation shale (Figures 5(a)-5(c)). Cracks can be observed between organic matter and mineral particles under high magnification (Figure 5(c)). Some organic matter developed pores, which were not subrotund or elliptical as usual but elongated and irregular (Figures 5(d) and 5(e)). The organic matter symbiotic with minerals, such as pyrite and quartz, always developed pores (Figures $5(\mathrm{f})-5(\mathrm{~h})$ and $5(\mathrm{p})$ ). Interparticle pores always appear along the rims of quartz and plagioclase, as well as in the pyrite framboids (Figures 5(i)-5(1)). Rims of detrital quartzes and plagioclase are always jagged, which leads to inter particle pores surviving consolidation and compaction. Pyrites were abundant in Dawuba Formation shale and occurred mostly as pyrite framboids (Figures 5(k) and 5(l)). Interparticle pores exist in pyrite framboids (Figure 5(1)). Many of interparticle pores and cracks occurred among clay minerals (Figures 5(m)-5(p)).
Some clay minerals exhibited sheet-like shapes because of compaction. Gaps occurred between these sheet-like clay minerals. For the Ar-ion polished samples, clay mineral pore types cannot be further identified and classified, because most clay minerals are not authigenic minerals of diagenetic genesis.

4.4. Porosity and Permeability. Samples with drilling orientation perpendicular to sedimentary stratification displayed relatively lower permeability than samples with drilling orientation parallel to sedimentary stratification, which explained the largest data point of the first member (Figure 6). In general, the first member shale samples possessed the inconspicuous highest porosity and permeability. Although one sample from the third member shale displayed lower permeability and porosity, totally speaking, no apparent difference of permeability and porosity occurred among the other three member shales (Figure 6). The abnormally higher permeability value for the first member shale sample may be reduced by factitious microfracture formed in sample interior during drilling process. Porosity displayed a positive correlation with the permeability for all the samples (Figure 6).

4.5. Gas-Containing Property. Through shale gas gathering system, the desorbed gas in Dawuba Formation shale ranged from $0.07 \mathrm{~cm}^{3} / \mathrm{g}$ to $1.28 \mathrm{~cm}^{3} / \mathrm{g}$, while the residual gas varied from $0.09 \mathrm{~cm}^{3} / \mathrm{g}$ to $0.44 \mathrm{~cm}^{3} / \mathrm{g}$. Some samples did not contain residual gas. The total shale gas content was in the scope of $0.07 \mathrm{~cm}^{3} / \mathrm{g}$ to $1.28 \mathrm{~cm}^{3} / \mathrm{g}$ (Figure 7 ). The first and third member shale samples presented much higher content of shale gas (Figure 7). It seems that these two member shales were favorable for development. However, the shale gas component showed different opinion through gas chromatographic 


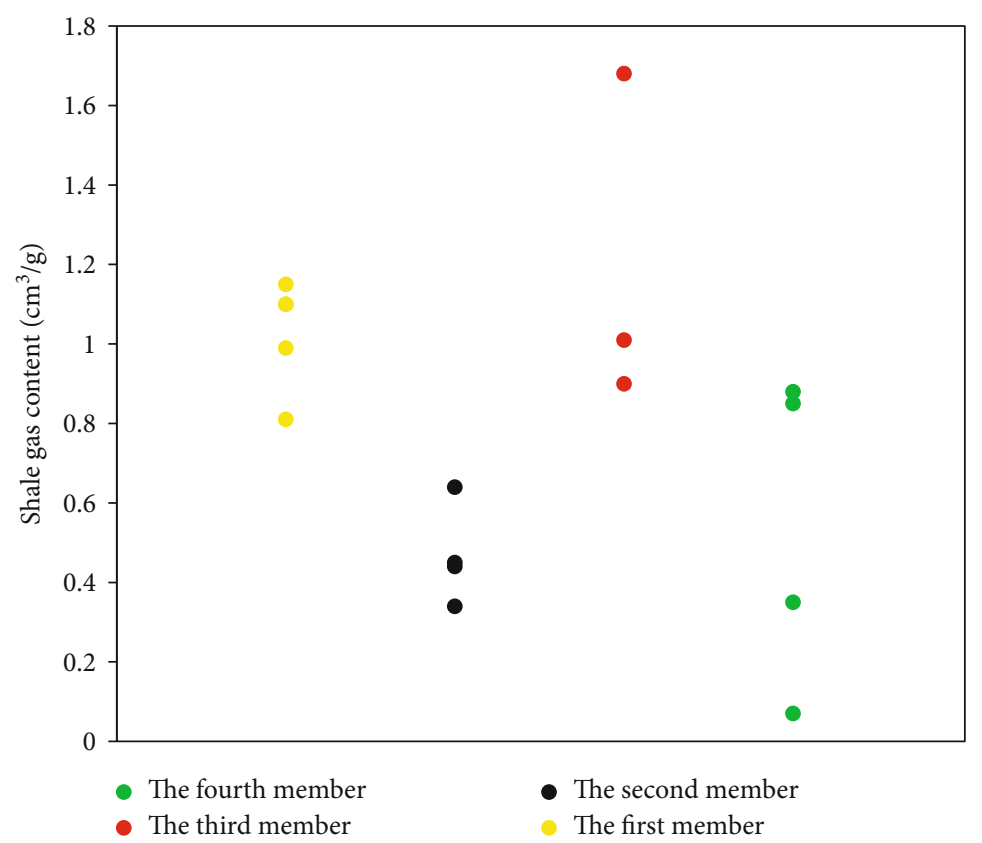

(a)

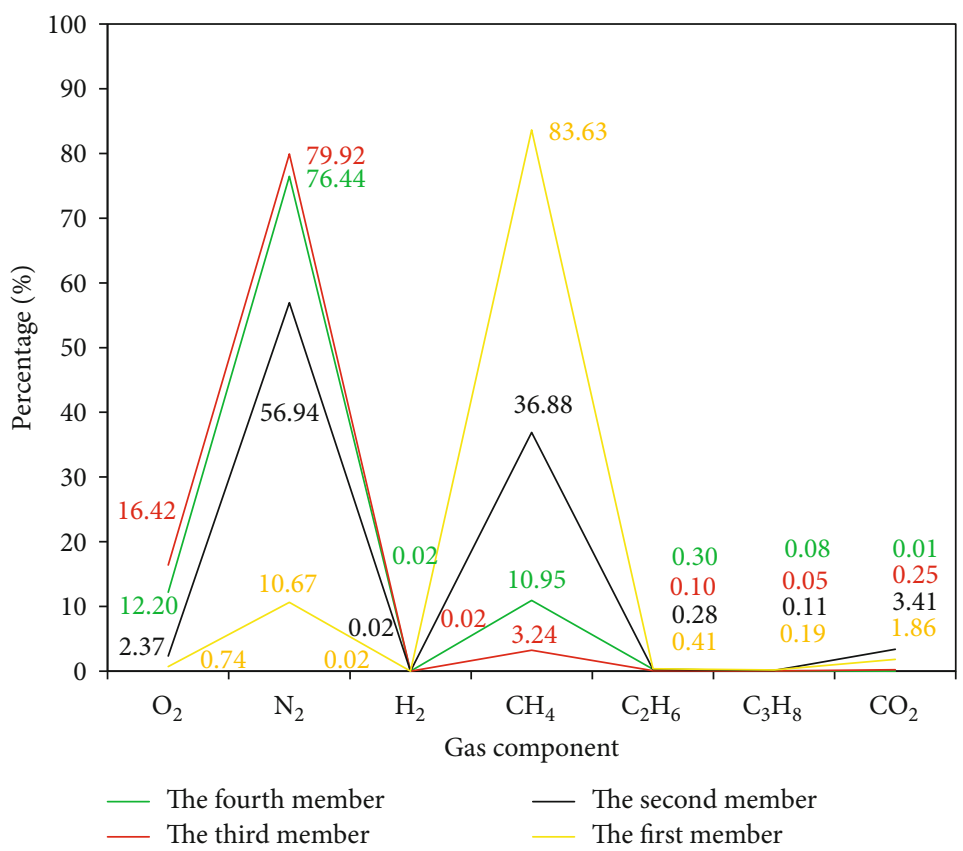

(b)

Figure 7: The shale gas content and components of the Dawuba Formation.

method. Only the shale gas gathered from the first member contained a large abundant of methane (83.63\%), followed by the second member shale samples (36.88\%) (Figure 7). The major component of shale gas in the other three member samples was nitrogen, which means no commercial production value.

4.6. Element Characteristics. The $\mathrm{Sr} / \mathrm{Ba}$ is a parameter sensitively reflecting the salinity of sedimentary water because of much stronger migration ability of $\mathrm{Sr}$ than $\mathrm{Ba}[39,40]$. It represents fresh water sedimentary environment when the $\mathrm{Sr} / \mathrm{Ba}$ value is less than 1 [38-41], which is exactly describing most of the Dawuba Formation shale samples (Figure 8). The $\mathrm{Sr} / \mathrm{Cu}$ is a parameter employed to express the dry-humid degree of sedimentary environment. The Sr/Cu values ranging from 1 to 10 represent warm-moist climate and larger than 10 reflect hot-dry climate $[37,39,42,43]$. $\mathrm{Sr} / \mathrm{Cu}$ values of most Dawuba Formation shale samples are larger than 10, which indicates hot-dry climate. However, some samples of the first member shale showed $\mathrm{Sr} / \mathrm{Ba}$ and $\mathrm{Sr} / \mathrm{Cu}$ values much larger than 1 and 40, respectively, which means relatively higher salinity of sedimentary water for the first 


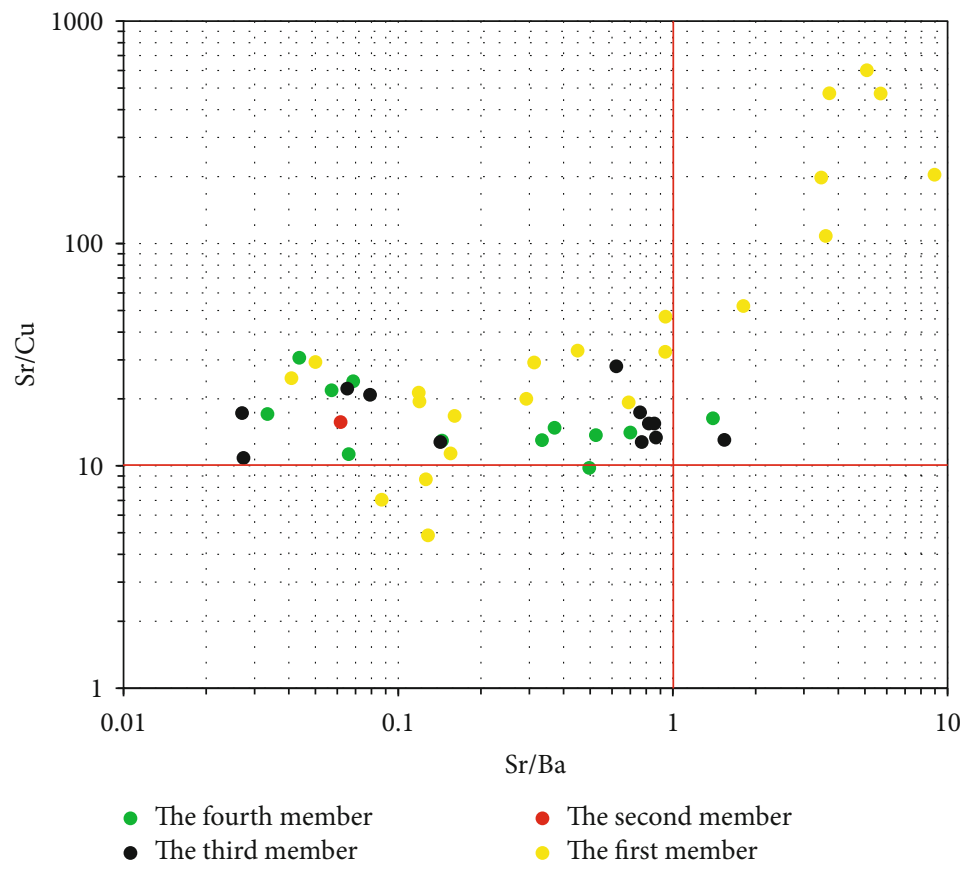

FIGURE 8: The relationship between $\mathrm{Sr} / \mathrm{Ba}$ and $\mathrm{Sr} / \mathrm{Cu}$.

member shale (Figure 8). A large quantity of parameters have been used to reflect the reducibility or oxidability of sedimentary environment, such as $\mathrm{Ce} / \mathrm{La}, \mathrm{Th} / \mathrm{U}, \mathrm{Cr} / \mathrm{Cu}$, and $\mathrm{V} / \mathrm{Sc}[36$, 38, 44-46]. Compared with the other three member shales, the first member shale presented obviously much lower $\mathrm{Ce} / \mathrm{La}, \mathrm{Th} / \mathrm{U}, \mathrm{Cr} / \mathrm{Cu}$, and $\mathrm{V} / \mathrm{Sc}$ values, which represented a stronger reducing environment (Figure 9). The first member shale might develop under much deeper and stratified water. Water below with more mineral ions cannot be mixed with the fresh water on top in view of density differences.

\section{Discussion}

5.1. Sedimentary Environment and Shale Thickness. The whole Dawuba Formation is characterized by a set of platform edge slope facies and platform basin facies deposits. The content of sand in the strata near the platform increased, while the content of silica in the strata near the basin increased [47-49]. In the early Carboniferous period, the seawater of Qinfang basin and Ailaoshan basin in the Tethys domain invaded along the sedimentary basin from southeast to northwest. The Ziyun area was stretched into a rifting basin under the action of NE-NW stress [50]. Due to the rapid transgression and insufficient material supply, the first member of the Dawuba Formation in deep water was deposited in the basin and mainly consisted of black shale and siliceous rock (Figure 10). At this time, the southwest of Ziyun area was the sedimentary center, and the shale thickness in the Ziyun area represented by Sidazhai outcrop was the largest (Figure 10). In the north, there was no deposit of shale strata because it was not within the range of the rift basin. During Ziyun tectonic movement, transgression gradually increased, and water body became shallow gradually from the trough internal to both sides. Material continued in sup- plying from the north and north east of Ziyun area. A thin layer of silty sand rock with gray, silty mudstones, colored marl of the lithologic combination was formed, which was called the upper strata of Dawuba Formation (Figure 10). Subsequently, with the continuous uplift of the structure, the water body continued to become shallower. The thick carbonate rocks of the Nandan Formation were formed and covered over the Dawuba Formation.

The shale thickness in Ziyun area was obviously affected by sedimentary facies and gradually thickened from northeast to southwest (Figure 11), with the maximum sedimentary thickness of nearly $400 \mathrm{~m}$ [51]. The first and third members of the Dawuba Formation in the north of Ziyun area were dominated by organic-enriched shale, which was about $40-170 \mathrm{~m}$ in in the first member and less than $50 \mathrm{~m}$ in the third member. However, the changes of sedimentary facies occurred in the north of Maoying, and the Dawaba Formation changed from mud-shale system to limestonemarl system. To the south of Ziyun area, the thickness of the Dawuba Formation increased significantly, reaching over $300 \mathrm{~m}$. The first and third members of Dawuba Formation were still intensively compose of black shale, while the second and fourth members changed from sandstone combined with mudstone and marl in the north to gray marl with thin layer siliceous rock. The thickness of Dawuba Formation in the eastern Ziyun area gradually decreased, and the stratification characteristic was fuzzy. But, the organic-enriched shale was still developed in the first and third members, and in the first member was about $70 \mathrm{~m}$ thick; the third member was about $20 \mathrm{~m}$ thick. The second member was composed of only a few meters of black shale with grey black lens marl, and the fourth member consisted of a set of grey black and dark grey silty mudstone with mud shale. It is generally concluded that the first and third members of the Dawuba Formation were 


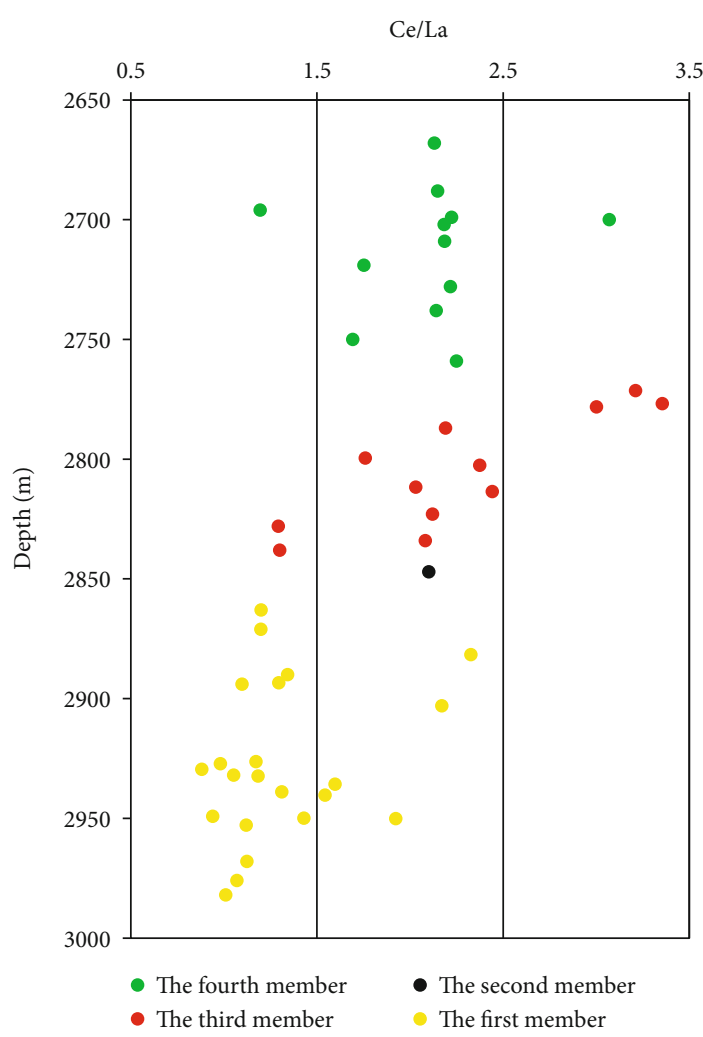

(a)

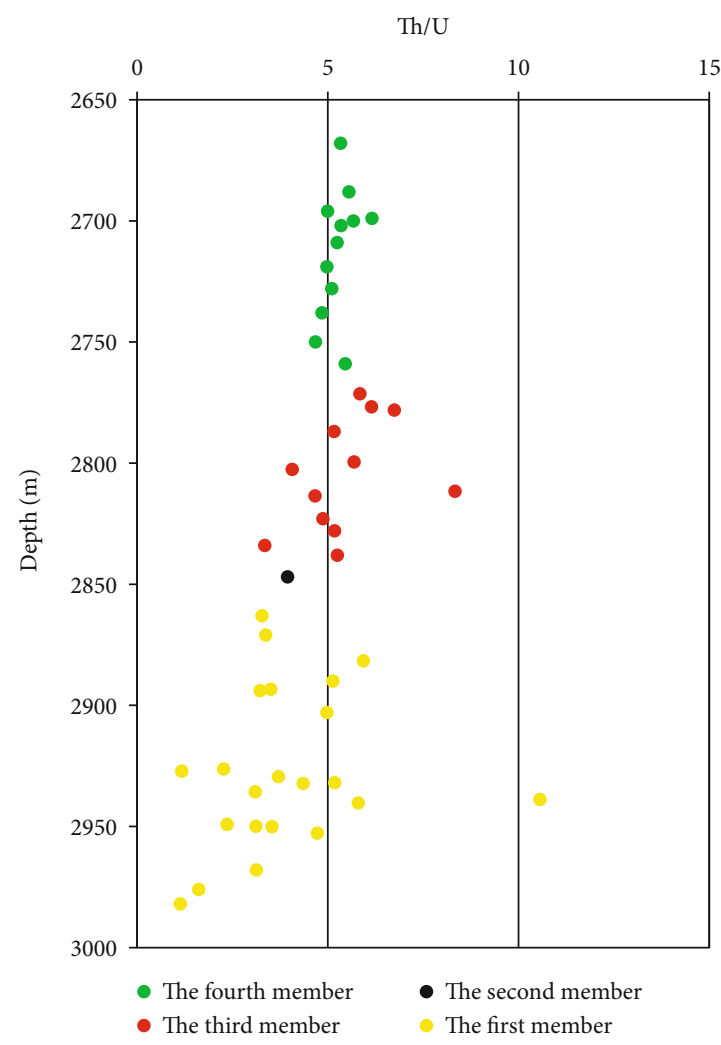

(c)

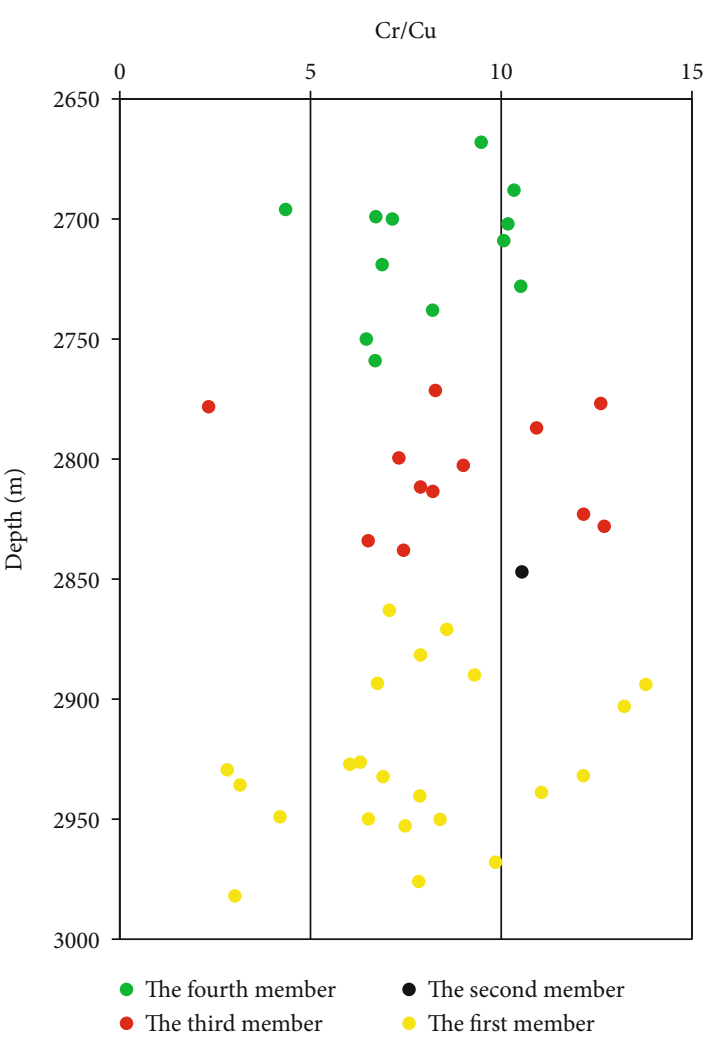

(b)

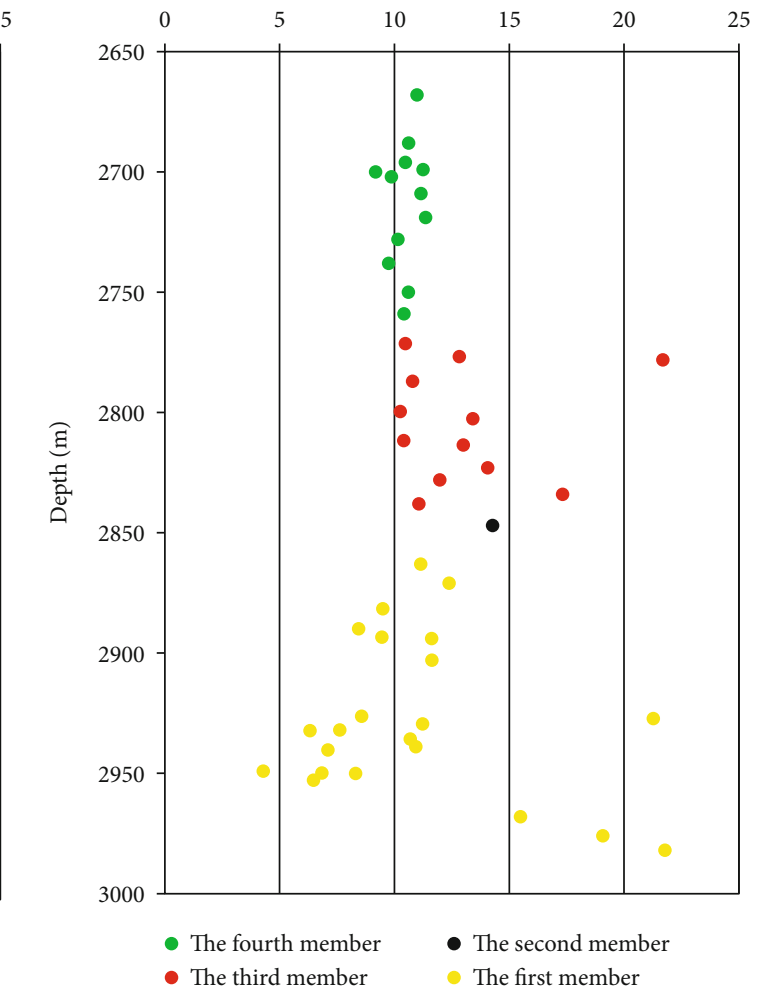

(d)

FIGURE 9: The resolution comparison of reducing environment exquisite changes for variety of parameters: (a) cross plot of Ce/La values and depth for the four member shale samples; (b) cross plot of $\mathrm{Cr} / \mathrm{Cu}$ values and depth for the four member shale samples; (c) cross plot of Th/U values and depth for the four member shale samples; (d) cross plot of V/Sc values and depth for the four member shale samples. 

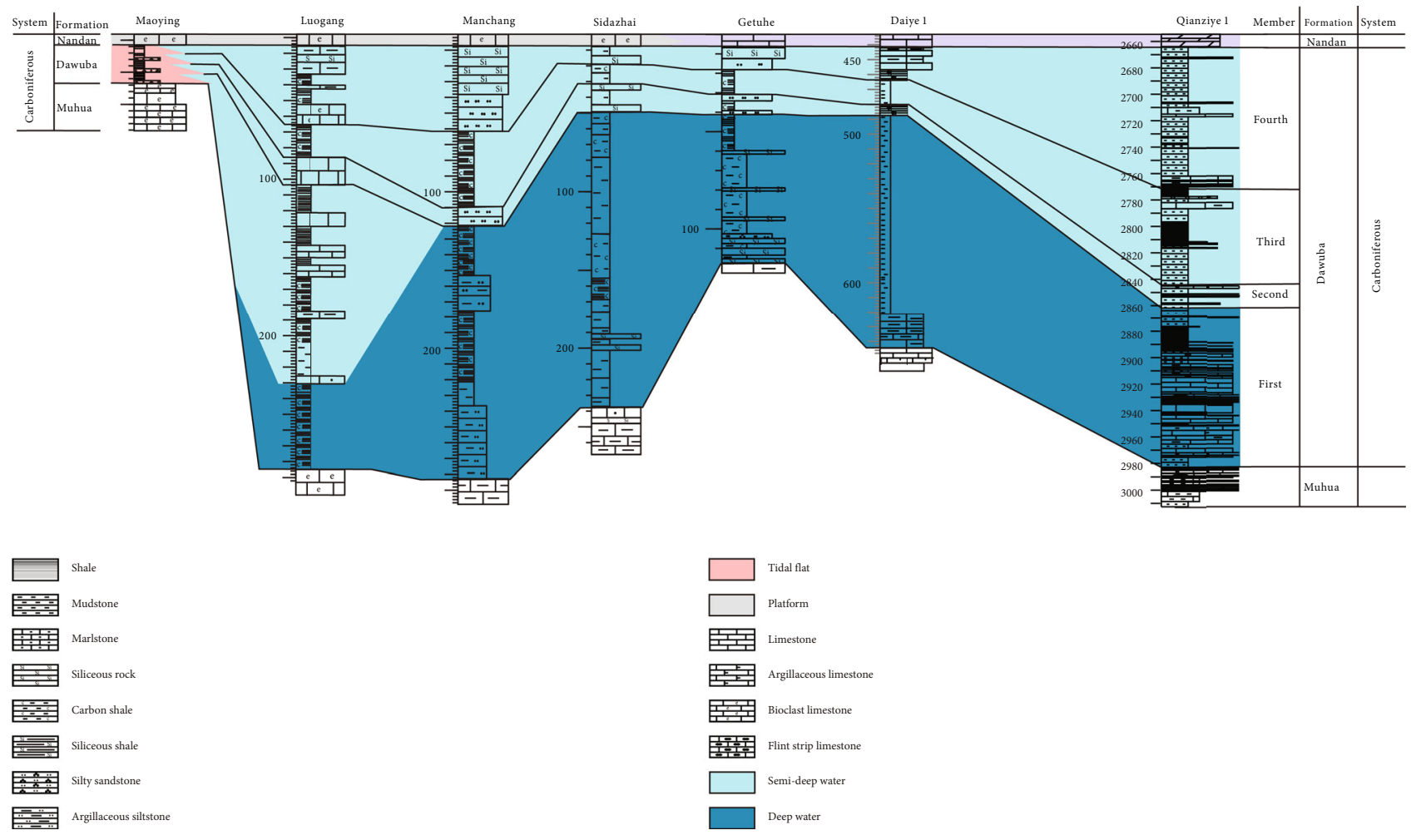

Figure 10: Columnar contrast map of the Dawuba Formation in Ziyun area. The section line of wells and outcrops connecting was shown in Figure 1 (the yellowish-brown one).

the most intensively and consistently organic-rich shale layers. From the perspective of lithologic characteristics, limestone and marl mostly developed at the bottom of the first member, and then, shale widely developed. In the third member, mudstone and shale developed with marl strips. The proportion of black shale in the second and fourth members of the Dawuba Formation is relatively small. Except for sandstone and siliceous rocks with continuous thickness of more than 3 meters, the proportion of shale is less than $50 \%$.

In fact, the Dawuba Formation was deposited during a transgressive-regressive cycle, which included several sea level eustacy of small scale. The transgression began during the first member deposition period and reached its climax. During most of this transgression, the bottom waters of the first member were oxygen poor (anoxic to euxinic), allowing for preservation of the abundant organic matter. During the third member deposition period, a transgressive of smaller scale happened, but the redox conditions never fully returned to the anoxic conditions of the first member, so in general, organic-matter abundances are lower in black shale from the Upper Dawuba Formation than in black shale from the Lower Dawuba Formation.

5.2. Comparative Evaluation of the Dawuba Formation Shale. As an important shale gas survey target in the southern Guizhou depression, the Carboniferous Dawuba Formation shale was characterized by large thickness, high TOC, and high gas-bearing content. By comparing and analyzing the shale thickness, sedimentary environment, organic geochemical characteristics, reservoir characteristics, and gas-bearing property, the four members of the Dawuba Formation in Ziyun area were evaluated.

The fourth member of Dawuba Formation was mainly black carbonaceous mudstone mixed with siliceous rocks and limestone deposited in half deep water, and gray mudstone was developed locally. The strata thickness of the fourth member was about $20-105 \mathrm{~m}$. The organic-enriched shale strata was relatively thin, merely about $2-30 \mathrm{~m}$, and the continuous thickness of shale is small. The TOC was in the range of $0.38-2.26 \%$ with an average of $0.99 \%$. The major gas component was nitrogen. The third member was one of the major shale strata with thickness of $10-70 \mathrm{~m}$. It was mainly composed of black carbonaceous shale with siliceous rocks with thickness for $5-45 \mathrm{~m}$. The thickness thinned gradually from south west to north east. It was deposited under semideep water and reductive environment. The TOC was in the scope of $0.97-4.25 \%$ with an average of $2.44 \%$. The third member contained a large scale of shale gas, but the major component was nitrogen, which is the similar component as the gas in the Lower Cambrian shale of Xiuwu Basin in the Lower Yangtze [7]. It was obvious that the third member of the Carboniferous Dawuba Formation shale in the southern Guizhou depression was not sealed well as the Wufeng-Longmaxi Formation shale in Sichuan Basin [12]. The second member of the Dawuba Formation had a thin thickness, generally less than $20 \mathrm{~m}$. The obvious feature is mudstone interbedded with limestone and was formed under the oxidation environment of semideep water. The shale was thin, with a thickness of less than $5 \mathrm{~m}$ and the single layer of shale much thinner. The content of organic carbon is 

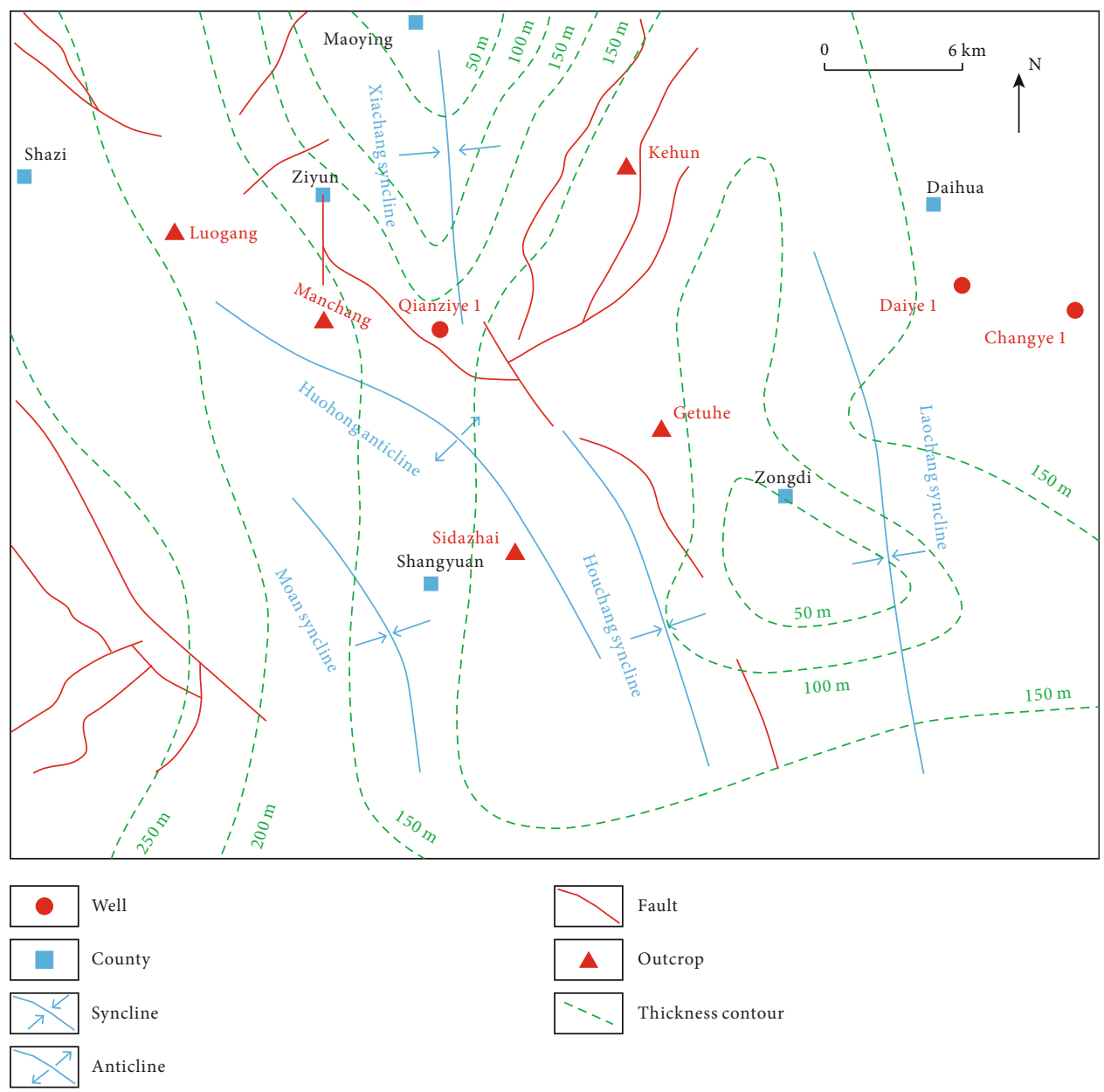

FIgURE 11: Stratum thickness contour map of Dawuba Formation.

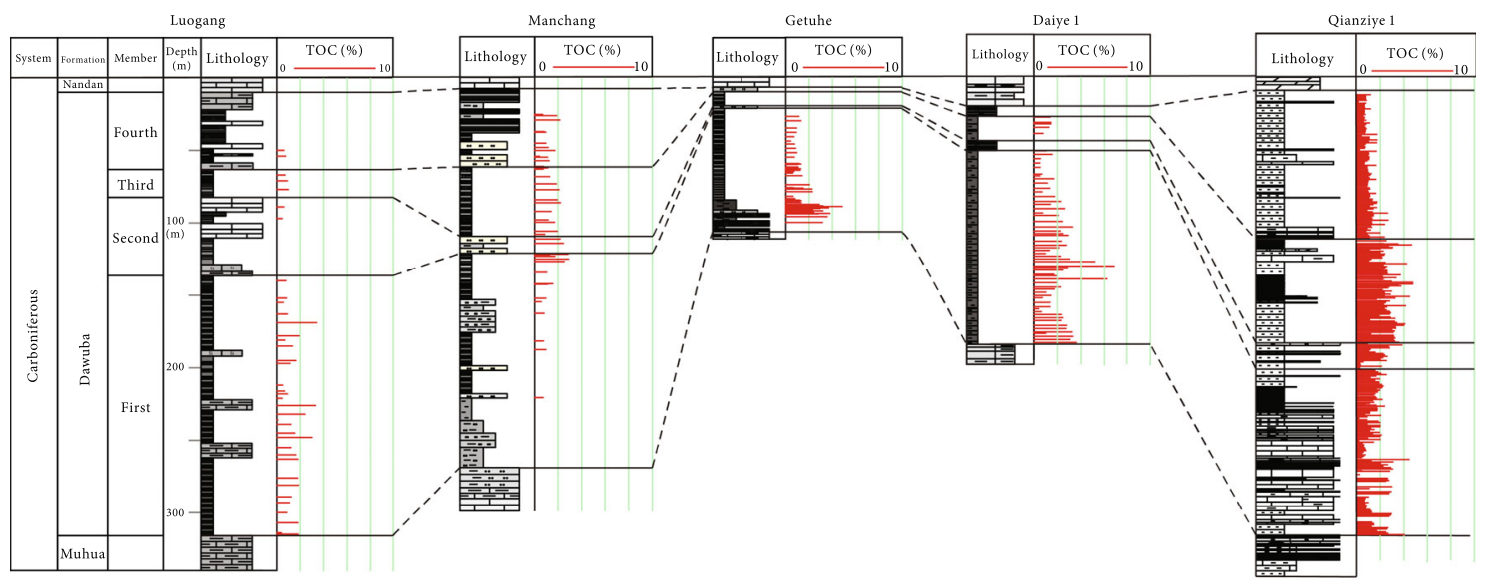

\begin{tabular}{|c|c|}
\hline$=$ & Shale \\
\hline 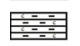 & $\begin{array}{l}\text { Carbon } \\
\text { shale }\end{array}$ \\
\hline 독 & Limestone \\
\hline & Mudstone \\
\hline & 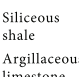 \\
\hline
\end{tabular}

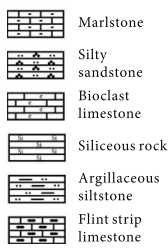

Figure 12: The TOC comparison of typical stratigraphic section of Dawuba Formation in Ziyun area. The section line of wells and outcrops connecting was shown in Figure 1 (the green one). 
relatively low, with an average TOC of $1.59 \%$. The shale in this member basically contains no gas. The first member of Dawuba Formation was mainly composed of organicenriched shale with silty sand a small amount of marl limestone at the bottom. The formation thickness was usually more than $100 \mathrm{~m}$, and the proportion of shale in the formation is relatively high. The elemental analysis indicated that the shale strata in the first member was formed in a relatively stagnant and reducing environment. The TOC was in the range of $0.96-4.66 \%$, with an average of $1.92 \%$. Moreover, the shale gas content was higher, and the shale gas mainly consisted of methane.

In general, the TOC vertically increased gradually from the fourth member to the first member of Dawuba Formation. On the plane, the organic carbon content increased gradually from north to south (Figure 12). The southern part of Ziyun area in early Carboniferous period is near the center of the rift basin, and the water is relatively deep, which is conducive to the accumulation of organic matter.

\section{Conclusion}

The shale intervals of the Dawuba Formation in Ziyun area of South Qian Depression were evaluated through mineral composition, organic matter character, pores, porosity, and permeability, as well as gas-containing property.

(1) The Dawuba Formation had a stable distribution in Ziyun area and was mainly composed of platform and basin facies deposits. According to the stratigraphic development characteristics and lithofacies association law of Dawuba Formation, the Dawuba Formation was divided into four members, among which the first and third members were organicrich shale strata

(2) The type of shale organic matter in Dawuba Formation in Ziyun area was mostly $\mathrm{II}_{2}$ kerogen. The TOC content ranged from 0.38 to $4.66 \%$, with an average of $1.73 \%$. Ro was in the range of $2.85 \%$ and $5.14 \%$, which indicated a stage of overmature evolution. The mineral composition is mainly quartz and clay minerals, and the brittle mineral content is more than $45 \%$, which has good compressibility. The shale gas content was in the scope of $0.07-1.68 \mathrm{~cm}^{3} / \mathrm{g}$

(3) The shale in the first and third members of Dawuba Formation was characterized by high TOC, high evolution degree, and high brittle mineral content, which indicated favorable shale strata. However, the shale gas in the third member mainly consisted of nitrogen, while that in the first member was chiefly composed of methane. Hence, the first member should be regarded as the most favorable target

\section{Data Availability}

The data has been included in the manuscript.

\section{Conflicts of Interest}

The authors declare that they have no conflicts of interest.

\section{Acknowledgments}

This study was supported by the China Geological Survey Projects "Geological survey of shale gas in GuizhongNanpanjiang area" (grant no. DD20190088). We thank Guoheng Liu at China University of Petroleum (East China) for his help in these experiments.

\section{References}

[1] K. A. Bowker, "Barnett shale gas production, Fort Worth Basin: issues and discussion," AAPG Bulletin, vol. 91, no. 4, pp. 523-533, 2007.

[2] D. M. Jarvie, R. J. Hill, T. E. Ruble, and R. M. Pollastro, "Unconventional shale-gas systems: the Mississippian Barnett shale of north-central Texas as one model for thermogenic shale-gas assessment," AAPG Bulletin, vol. 91, no. 4, pp. 475-499, 2007.

[3] J. C. Zhang, "Exploration potential of shale gas resources in China," Natural Gas Industry, vol. 28, no. 6, pp. 136-140, 2008.

[4] C. Zou, Q. Zhao, D. Dong et al., "Geological characteristics, main challenges and future prospect of shale gas," Journal of Natural Gas Geoscience, vol. 2, no. 5-6, pp. 273-288, 2017.

[5] G. Liu, G. Zhai, C. Zou et al., "A comparative discussion of the evidence for biogenic silica in Wufeng- Longmaxi siliceous shale reservoir in the Sichuan basin, China," Marine and Petroleum Geology, vol. 109, pp. 70-87, 2019.

[6] G. Zhai, Y. Wang, G. Liu et al., "The Sinian-Cambrian formation shale gas exploration and practice in southern margin of Huangling paleo-uplift," Marine and Petroleum Geology, vol. 109, pp. 419-433, 2019.

[7] K. Zhang, C. Jia, Y. Song et al., "Analysis of Lower Cambrian shale gas composition, source and accumulation pattern in different tectonic backgrounds: a case study of Weiyuan Block in the Upper Yangtze region and Xiuwu Basin in the Lower Yangtze region," Fuel, vol. 263, p. 115978, 2020.

[8] K. Zhang, Y. Song, S. Jiang et al., "Shale gas accumulation mechanism in a syncline setting based on multiple geological factors: an example of southern Sichuan and the Xiuwu Basin in the Yangtze region," Fuel, vol. 241, pp. 468-476, 2019.

[9] T. L. Guo and H. R. Zhang, "Formation and enrichment mode of Jiaoshiba shale gas field, Sichuan Basin," Petroleum Exploration and Development, vol. 41, no. 1, pp. 31-40, 2014.

[10] C. Han, M. Han, Z. Jiang et al., "Source analysis of quartz from the Upper Ordovician and Lower Silurian black shale and its effects on shale gas reservoir in the southern Sichuan Basin and its periphery, China," Geological Journal, vol. 54, no. 1, pp. 439-449, 2019.

[11] K. Zhang, Y. Song, S. Jiang et al., "Mechanism analysis of organic matter enrichment in different sedimentary backgrounds: a case study of the Lower Cambrian and the Upper Ordovician-Lower Silurian, in Yangtze region," Marine and Petroleum Geology, vol. 99, pp. 488-497, 2019.

[12] K. Zhang, Y. Song, C. Jia et al., "Vertical sealing mechanism of shale and its roof and floor and effect on shale gas accumulation, a case study of marine shale in Sichuan basin, the Upper 
Yangtze area," Journal of Petroleum Science and Engineering, vol. 175, pp. 743-754, 2019.

[13] K. Zhang, Z. Jiang, L. Yin et al., "Controlling functions of hydrothermal activity to shale gas content-taking Lower Cambrian in Xiuwu Basin as an example," Marine and Petroleum Geology, vol. 85, pp. 177-193, 2017.

[14] K. Zhang, J. Peng, W. Liu et al., "The role of deep geofluids in the enrichment of sedimentary organic matter: a case study of the Late Ordovician-Early Silurian in the upper Yangtze region and early Cambrian in the lower Yangtze region, South China," Geofluids, vol. 2020, Article ID 8868638, 12 pages, 2020.

[15] R. Y. Wang, Z. Q. Hu, and H. K. Nie, "Comparative analysis and discussion of shale reservoir characteristics in the Wufeng-Longmaxi and Niutitang formations," Petroleum Geology \& Experiment, vol. 40, no. 5, pp. 639-649, 2018.

[16] T. Dong, N. B. Harris, K. Ayranci, and S. Yang, "The impact of rock composition on geomechanical properties of a shale formation: Middle and Upper Devonian Horn River Group shale, Northeast British Columbia, Canada," AAPG Bulletin, vol. 101, no. 2, pp. 177-204, 2017.

[17] G. Liu, Z. Huang, Z. Jiang, J. Chen, F. Chen, and J. Xing, "Gas adsorption capacity calculation limitation due to methane adsorption in low thermal maturity shale: a case study from the Yanchang Formation, Ordos Basin," Journal of Natural Gas Science and Engineering, vol. 30, pp. 106-118, 2016.

[18] G. Liu, Z. Huang, F. Chen et al., "Reservoir characterization of Chang 7 member shale: a case study of lacustrine shale in the Yanchang Formation, Ordos Basin, China," Journal of Natural Gas Science and Engineering, vol. 34, pp. 458-471, 2016.

[19] Z. Huang, G. Liu, T. Li, Y. Li, Y. Yin, and L. Wang, "Characterization and control of mesopore structural heterogeneity for low thermal maturity shale: a case study of Yanchang Formation shale, Ordos Basin," Energy \& Fuels, vol. 31, no. 11, pp. 11569-11586, 2017.

[20] G. Liu, B. Liu, Z. Huang et al., "Hydrocarbon distribution pattern and logging identification in lacustrine fine-grained sedimentary rocks of the Permian Lucaogou Formation from the Santanghu basin," Fuel, vol. 222, pp. 207-231, 2018.

[21] G. Liu, G. Zhai, Z. Huang et al., "The effect of tuffaceous material on characteristics of different lithofacies: a case study on Lucaogou Formation fine-grained sedimentary rocks in Santanghu Basin," Journal of Petroleum Science and Engineering, vol. 179, pp. 355-377, 2019.

[22] J. Ma, G. Liu, Z. Huang, G. Ou, T. Li, and X. Guo, "Tight tuff reservoir characteristics and its controlling factors: a comparative study of the Permian Tiaohu Formation and carboniferous Haerjiawu Formation in the Santanghu Basin, NW China," Journal of Petroleum Science and Engineering, vol. 187, p. 106808, 2020.

[23] X. ZHAO, L. ZHOU, P. U. Xiugang et al., "Geological characteristics of shale rock system and shale oil exploration breakthrough in a lacustrine basin: a case study from the Paleogene 1st sub- member of Kong 2 Member in Cangdong sag, Bohai Bay Basin, China," Petroleum Exploration and Development, vol. 45, no. 3, pp. 377-388, 2018.

[24] X. Guo, D. Hu, R. Liu, X. Wei, and F. Wei, "Geological conditions and exploration potential of Permian marine-continent transitional facies shale gas in the Sichuan Basin," Natural Gas Industry, vol. 38, no. 10, 2018.

[25] S. J. Bao, T. Lin, and H. K. Nie, "Preliminary study of the transitional facies shale gas reservoir characteristics: taking Perm- ian in the Xiangzhong depression as an example," Earth Science Frontiers, vol. 23, no. 1, pp. 44-53, 2016.

[26] G. Y. Zhai, Y. F. Wang, and G. H. Liu, "Enrichment and accumulation characteristics and prospect analysis of the Permian marine continental multiphase shale gas in China," Sedimentary Geology and Tethyan Geology, vol. 40, no. 3, pp. 102117, 2020.

[27] X. D. Wang and Y. Jin, "Geochemical features and sedimentary conditions of the Middle-Devonian shale in the northwestern Central-Guangxi depression," Journal of Stratigraph, vol. 2, 2000.

[28] K. Yuan, K. Y. Wang, and S. H. Gong, "Shale gas enrichment features and impacting factors in carboniferous Dawuba Formation, southern Guizhou area," Coal Geology of China, vol. 3, pp. 28-34, 2018.

[29] Z. H. Yang, Z. M. Li, and B. J. Shen, "Shale gas accumulation conditions and exploration prospect in southern Guizhou depression," China Petroleum Exploration, vol. 3, pp. 24-28, 2009.

[30] Z. Y. Xu, G. S. Yao, and Q. X. Guo, "Genetic interpretation about geotectonics and structural transfiguration of the southern Guizhou depression," Geotectonica et Metallogenia, vol. 34, no. 1, pp. 20-31, 2010.

[31] S. F. Lu, B. He, and S. J. Du, "Geological conditions and exploration prospect of shale gas in Dawuba Formation of Lower Carboniferous of Daiye-1 well in southern Guizhou Province," Geological Survey of China, vol. 3, pp. 4-11, 2016.

[32] G. R. Chalmers, R. M. Bustin, and I. M. PowerCharacterization of gas shale pore systems by porosimetry, pycnometry, surface area, and field emission scanning electron microscopy/transmission electron microscopy image analyses: examples from the Barnett, Woodford, Haynesville, Marcellus, and Doig units,” AAPG Bulletin, vol. 96, pp. 1099-1119, 2011.

[33] X. Cui, R. M. Bustin, and R. Brezovski, "A new method to simultaneously measure in-situ permeability and porosity under reservoir conditions: implications for characterization of unconventional gas reservoirs," in Society of Petroleum Engineers, Canadian Unconventional Resources and International Petroleum Conference, pp. 19-21, Calgary, Alberta, Canada, 2010.

[34] A. Ghanizadeh, A. Amann-Hildenbrand, M. Gasparik, Y. Gensterblum, B. M. Krooss, and R. Littke, "Experimental study of fluid transport processes in the matrix system of the European organic-rich shales: II. Posidonia Shale (Lower Toarcian, northern Germany)," International Journal of Coal Geology, vol. 123, pp. 20-33, 2014.

[35] K. Hiroto, "Ocean anoxic event at the Precambrian-Cambrian boundary. Geology, 29 (11). Translated by Wen F. Y., 2002," Marine Geology Letters, vol. 18, no. 4, pp. 33-35, 2001.

[36] L. Tonger, X. WH, and Y. C, "The discussion on anoxic environments and its geochemical identifying indices," Acta Sedimentologica Sinica, vol. 22, no. 2, pp. 365-372, 2004.

[37] G. Liu and D. S. Zhou, "Application of trace elements analysis in identifying sedimentary environment: taking Qianjiang Formation in the Jianghan Basin as an example," Petroleum Geology and Experiment, vol. 29, no. 3, pp. 307-310, 2007.

[38] C. Du, B. Zhang, and S. T. Zhang, "Application and principle of element geochemistry in the evolution of lake sedimentary environment," Geology and Resources, vol. 21, no. 5, pp. 487492, 2012. 
[39] Y. H. Fan, H. J. Qu, and H. Wang, "The application of trace elements analysis to identifying sedimentary media environment: a case study of Late Triassic strata in the middle part of western Ordos Basin," Geology in China, vol. 39, no. 2, pp. 382-389, 2012.

[40] R. C. Zheng and M. Q. Liu, "Study on palaeo-salinity of Chang-6 oil reservoir set in Ordos Basin," Oil \& Gas Geology, vol. 20, no. 1, pp. 20-25, 1999.

[41] E. Custodio, "Aquifer overexploitation: what does it mean?," Hydrogeology Journal, vol. 10, no. 2, pp. 254-277, 2002.

[42] A. Leman, Chemical Geology and Physics of Lake, S. M. Wang, Ed., Geological Publishing House, Beijing, 1989.

[43] H. W. Deng and K. Qian, Sedimentary Geochemistry and Environment Analysis, Gansu Science and Technology Press, Lanzhou, 1993.

[44] J. R. Hatch and J. S. Leventhal, "Relationship between inferred redox potential of the depositional environment and geochemistry of the Upper Pennsylvanian (Missourian) Stark Shale Member of the Dennis Limestone, Wabaunsee County, Kansas, U.S.A," Chemical Geology, vol. 99, no. 1-3, pp. 65-82, 1992.

[45] B. J. Jones and A. C. Manning, "Comparison of geochemical indices used for the interpretation of palaeo-redox conditions in ancient mudstones," Palaeo-geography Palaeo-climatology Palaeo-ecology, vol. 111, pp. 111-129, 1994.

[46] G. M. Alberdi and R. Tocco, "Trace metals and organic geochemistry of the Machiques Member (Aptian-Albian) and La Luna Formation (Cenomanian-Campanian), Venezuela," Chemical Geology, vol. 160, no. 1-2, pp. 19-38, 1999.

[47] Z. Z. Feng, Y. Q. Yang, and Z. D. Bao, "Lithofacies palaeogeography of the carboniferous in South China," Journal of Palaeogeography, vol. 1, pp. 75-86, 1999.

[48] K. Yuan, R. Chen, and T. Lin, "Petrological characteristics and sedimentary environment in the southern Guizhou during the Late Carboniferous," Petroleum Geology \& Experiment, vol. 41, no. 1, pp. 38-44, 2019.

[49] S. F. Tian and R. D. Yang, "Lithofacies and paleogeography evolution and characteristics of shale gas accumulation in Lower Carboniferous, Guizhou, China," Journal of Chengdu University of Technology (Science \& Technology Edition), vol. 3, pp. 291-299, 2016.

[50] H. D. Chen and Y. F. Zeng, "Nature and evolution of the Youjiang Basin," Sedimentary Facies and Palaeogeography, vol. 1, pp. 28-37, 1990.

[51] Y. Y. An, H. B. Fu, and H. G. Chen, "Reservoir property and control factors of shale gas of Dawuba Formation, Lower Carboniferous in South Guizhou-with Changye No. 1 reservior as an example," Guizhou Geology, vol. 32, pp. 181-189, 2015. 